\title{
Estimation of a maximum Lu diffusion rate in a natural eclogite garnet
}

\section{Journal Article}

\section{Author(s):}

Skora, Susanne; Baumgartner, Lukas; Mahlen, Nancy; Lapen, Thomas; Johnson, Clark; Bussy, Francois

Publication date:

2008-12

Permanent link:

https://doi.org/10.3929/ethz-b-000105033

Rights / license:

In Copyright - Non-Commercial Use Permitted

Originally published in:

Swiss Journal of Geosciences 101(3), https://doi.org/10.1007/s00015-008-1268-y 


\title{
Estimation of a maximum Lu diffusion rate in a natural eclogite garnet
}

\author{
Susanne Skora ${ }^{1, *}$,Lukas P. Baumgartner ${ }^{1}$, NAnCy J. MAhlen ${ }^{2}$, Thomas J. LAPen ${ }^{3}$, Clark M. Johnson ${ }^{2}$ \\ \& FRANÇOIS BUSSY ${ }^{1}$
}

Key words: alpine eclogites, Lu zoning, volume diffusion, Lu/Hf, Sm/Nd, closure temperature

\begin{abstract}
Lutetium zoning in garnet within eclogites from the Zermatt-Saas Fee zone, Western Alps, reveal sharp, exponentially decreasing central peaks. They can be used to constrain maximum $\mathrm{Lu}$ volume diffusion in garnets. A prograde garnet growth temperature interval of $\sim 450-600^{\circ} \mathrm{C}$ has been estimated based on pseudosection calculations and garnet-clinopyroxene thermometry. The maximum pre-exponential diffusion coefficient which fits the measured central peak is in the order of $\mathrm{D}_{0}=5.7 * 10^{-6} \mathrm{~m}^{2} / \mathrm{s}$, taking an estimated activation energy of $270 \mathrm{~kJ} / \mathrm{mol}$ based on diffusion experiments for other rare earth elements in garnet. This corresponds to a maximum diffusion rate of $\mathrm{D}\left(\sim 600^{\circ} \mathrm{C}\right)=4.0^{*} 10^{-22} \mathrm{~m}^{2} / \mathrm{s}$. The diffusion estimate of Lu can be used to es-
\end{abstract}

timate the minimum closure temperature, $\mathrm{T}_{\mathrm{c}}$, for $\mathrm{Sm}-\mathrm{Nd}$ and $\mathrm{Lu}-\mathrm{Hf}$ age data that have been obtained in eclogites of the Western Alps, postulating, based on a literature review, that $\mathrm{D}(\mathrm{Hf})<\mathrm{D}(\mathrm{Nd}) \leq \mathrm{D}(\mathrm{Sm}) \leq \mathrm{D}(\mathrm{Lu}) . \mathrm{T}_{\mathrm{c}}$ calculations, using the Dodson equation, yielded minimum closure temperatures of about $630{ }^{\circ} \mathrm{C}$, assuming a rapid initial exhumation rate of $50 \% \mathrm{~m}$.y., and an average crystal size of garnets $(\mathrm{r}=1 \mathrm{~mm})$. This suggests that $\mathrm{Sm} / \mathrm{Nd}$ and $\mathrm{Lu} / \mathrm{Hf}$ isochron age differences in eclogites from the Western Alps, where peak temperatures did rarely exceed $600{ }^{\circ} \mathrm{C}$ must be interpreted in terms of prograde metamorphism.

\section{Introduction}

The closure temperature, $\mathrm{T}_{\mathrm{c}}$, has been defined by Dodson (1973) to be "the temperature at the time corresponding to its apparent age". It is dependant on the diffusion rate, the cooling rate, grain size, and grain shape. Following Dodson (1973) for spherical minerals one obtains:

$\frac{Q}{R^{*} T_{c}}=\ln \left(-\frac{A * R^{*} T_{c}^{2} * D_{o} / r^{2}}{Q^{*} d T / d t}\right)$

( $\mathrm{Q}=$ activation energy; $\mathrm{R}=$ universal gas constant, $\mathrm{A}=\mathrm{nu}-$ merical geometry factor, $\mathrm{D}_{0}=$ diffusion coefficient at infinitely high temperatures, $\mathrm{r}=$ radius, $\mathrm{dT} / \mathrm{dt}=$ cooling rate). In terms of geochronology, the mineral specific $\mathrm{T}_{\mathrm{c}}$ determines, among other factors, whether its age represents the timing of mineral crystallization or whether it corresponds to an age where a particular isotope geochronometer was closed.
Garnet geochronology is particularly useful for systems such as Sm-Nd and Lu-Hf because this mineral has high ${ }^{147} \mathrm{Sm} /$ ${ }^{144} \mathrm{Nd}$ and ${ }^{176} \mathrm{Lu} /{ }^{177} \mathrm{Hf}$ ratios (e.g. Mezger et al. 1992; Duchêne et al. 1997). The stability relations of garnet are generally well understood, hence constraints can be placed on the age(s) of specific P-T conditions at which the mineral grew (e.g. Lapen et al. 2003; Whitehouse \& Platt 2003) provided garnet has not been heated beyond its $\mathrm{T}_{\mathrm{c}}$. Most $\mathrm{T}_{\mathrm{c}}$ studies so far concern Sm-Nd garnet geochronology because diffusion experiments exist for Sm and/or Nd in garnet (Harrison \& Wood 1980; Coghlan 1990; Ganguly et al. 1998; Van Orman et al. 2002; Tirone et al. 2005). However, published estimates for $\mathrm{Sm}-\mathrm{Nd} \mathrm{T}_{\mathrm{c}}$ ' span a large range in temperature from around $500{ }^{\circ} \mathrm{C}$ (e.g. Mezger et al. 1992) to around $800{ }^{\circ} \mathrm{C}$ (e.g. Jagoutz 1988). Not much is known about the $\mathrm{T}_{\mathrm{c}}$ of the Lu-Hf system, and, to our knowledge, no Lu and Hf diffusion data in garnet have been determined. In general, $\mathrm{Lu}-\mathrm{Hf}$ ages have been found to give older ages when compared to Sm-Nd ages. Scherer et al. (2000) concluded that in

\footnotetext{
${ }^{1}$ Institute of Mineralogy and Geochemistry, University of Lausanne, L'Anthropole, 1015 Lausanne, Switzerland.

${ }^{2}$ Department of Geology and Geophysics, University of Wisconsin-Madison, 1215 W. Dayton Street, Madison, WI 53706, USA.

${ }^{3}$ Department of Geosciences, University of Houston, 4800 Calhoun Road, Houston, TX 77204, USA.

* Presently: Department of Earth Sciences, University of Bristol, Wills Memorial Building, Queens Road, Bristol BS8 1RJ, United Kingdom.

E-mail: Susanne.Skora@bristol.ac.uk
} 
their high grade rocks this is likely due to a higher $T_{c}$ for the Lu-Hf, compared to the Sm-Nd system. Lapen et al. (2003) interpreted a similar age difference in lower temperature rocks to reflect prograde zoning, based on the fact that $\mathrm{Lu}$, in contrast to $\mathrm{Sm}$, will be strongly partitioned into garnet and hence, will be concentrated in the early grown core region. The knowledge whether prograde Lu-Hf zoning is preserved in a sample or not can be used to distinguish the two interpretations.

We found sharp, exponentially decreasing Lu-central peaks in garnets from eclogite-facies rocks of the Alps (Skora et al. 2006). They are considered to be of prograde origin and are used here to constrain a maximum $\mathrm{Lu}$ volume diffusion rate. We further evaluate their implications on the $\mathrm{T}_{\mathrm{c}}$ if garnet-bearing eclogites from the Western Alps are used for $\mathrm{Lu}-\mathrm{Hf}$ and Sm-Nd geochronology.

\section{Geological setting}

\section{Introduction}

The sample studied was collected in the area of Zermatt, Switzerland. Here, metamorphic relics of the Liguro-Piemont oceanic crust, which once separated the European margin from Apulia (African margin), are subdivided into the high (HP) to ultrahigh-pressure (UHP) Zermatt-Saas Fee (ZSF) zone and the structurally overlying, lower-pressure Tsaté nappe, a part of the Combin zone (e.g. Bearth 1967; Sartori 1987). The protoliths of the ZSF zone of the Liguro-Piemont oceanic crust are inferred to be $~ 160-165$ Ma old (e.g. Rubatto et al. 1998; Schaltegger et al. 2002). Subduction of the oceanic crust southwards below the African continent was initiated during Late Jurassic/Early Cretaceous times (e.g. Dewey et al. 1989). This was likely accompanied by the opening of the Valais ocean or basin at the European margin which led to the separation of the Briançonnais promontory from the European continent (e.g. Stampfli et al.1998). However, a recent study of Masson et al. (in press) yielded Carboniferous ages for the igneous relics of the Valais zone (Versoyen ophiolites), which challenges the existence of an oceanic floor in the Valais basin of Cretaceous age in the Western Alps.

Eclogite facies metamorphism of the northern ZSF zone was reached in Tertiary times ( 52-40 Ma: Bowtell et al. 1994; Rubatto et al. 1998; Amato et al. 1999; Mayer et al. 1999; Dal Piaz et al. 2001; Lapen et al. 2003; Mahlen et al. 2005, 2006; Gouzu et al.2006). These ages are partially in conflict with each other, and the interpretation of each of those ages is variable in the above cited literature (discussed below). Subsequent greenschist-facies overprinting occurred during exhumation (e.g. Bearth 1967; Barnicoat 1988; Müller 1989; Reddy et al. 1999; Cartwright \& Barnicoat 2002). The intensity of the greenschistfacies overprinting can be spatially linked to faults, albite veins, and tectonic contacts (cited above).

The ZSF zone is exposed in the Western Swiss/Italian Alps (Fig. 1). It contains all parts of a classic ophiolite sequence: ultramafic rocks (peridotites, serpentinites), gabbros and ba- salts, radiolarites, and calcareous and siliceous sediments (e.g. Bearth 1967; Dal Piaz \& Ernst 1978; Barnicoat \& Fry 1986). Pillow structures are preserved at the Pfulwe pass region (approximately $7 \mathrm{~km}$ E of Zermatt, Switzerland; Bearth 1967) as well as a possible sheeted dyke complex (Bowtell et al. 1994). Although the ZSF zone extends as a zone over $150 \mathrm{~km}$, it is internally complexly deformed and dismembered. Structurally, the ZSF zone, together with the associated overlying Tsaté nappe (upper Combin zone, Sartori (1987)), occurs sandwiched between the continental basement rocks of the overlying Dent Blanche and Grand St. Bernard nappes and the underlying Monte Rosa nappe (e.g. Bearth 1967; Escher et al. 1997).

\section{Review of metamorphic ages}

Metamorphic ages for the northern Zermatt-Saas Fee zone range between 52 and $40 \mathrm{Ma}$. Most of the obtained ages were interpreted to date the peak of metamorphism. We note that none of the petrological studies conducted in the area indicate that $\mathrm{T}_{\text {peak }}$ and $\mathrm{P}_{\text {peak }}$ were reached at significantly different stages during the metamorphic cycle. This is in contrast to studies of eclogites from the Central Alps (e.g. Brouwer et al. 2005), where $\mathrm{T}_{\text {peak }}$ was reached significantly later than $\mathrm{P}_{\text {peak }}$, during the subsequent alpine medium pressure metamorphism, caused by the collisional event. Hence $\mathrm{T}_{\text {peak }}$ and $\mathrm{P}_{\text {peak }}$ correspond to the deepest stage of subduction in the eclogites from the Western Alps, and is discussed in the text below as the peak metamorphic event.

A series of ages that were obtained with different dating techniques exist for the Lago di Cignana UHP unit $\left(\mathrm{T}_{\text {peak }} \sim 580\right.$ $630{ }^{\circ} \mathrm{C} ; \mathrm{P}_{\text {peak }} \sim 28-30 \mathrm{kbar}$; e.g. Reinecke 1998). A Lu-Hf garnet metamorphic age of $48.8 \pm 2.1$ Ma was obtained by Lapen et al. (2003). The authors proposed that their Lu-Hf age is skewed towards the onset of garnet growth because $\mathrm{Lu}$ is partitioned in the early-formed core of garnets. In contrast, $\mathrm{U}-\mathrm{Pb}$ ages of metamorphic zircon and zircon rims that occur in eclogite and metasediments yielded $44.1 \pm 0.7 \mathrm{Ma}$ (Rubatto et al. 1998) and were interpreted by these authors to date the deepest stage of subduction. This age is similar to the $43.2 \pm 1.1 \mathrm{Ma}$ and $44.4 \pm 1.5 \mathrm{Ma}$ in-situ Ar-Ar ages (Gouzu et al. 2006). These were obtained in phengite inclusions within garnets in metapelites. The dated phengites were found approximately half-way between the garnet centre and the rim. These ages have been interpreted by the authors to date or slightly postdate the peak metamorphic event, given that the Lago di Cignana UHP unit exceeds the closure temperatures for Ar/Ar in phengites ( 350-500 ${ }^{\circ}$ C; e.g. Purdy \& Jäger 1976; Villa 1998).

Several lines of evidence suggest that the $43-44 \mathrm{Ma} \mathrm{Ar} / \mathrm{Ar}$ and $\mathrm{U} / \mathrm{Pb}$ ages do not reflect peak metamorphism. Although the $T_{c}$ for Ar in phengite is below peak metamorphic conditions at Lago di Cignana, garnet is a generally slow diffusing mineral. To our knowledge, no Ar diffusion data in garnet exist. However, it might be comparable to He diffusion in garnet (Dunai \& Roselieb 1996) which is slow and comparable to rare earth element (REE) volume diffusion rates (discussed below)

638 s. Skora et al. 
at around $600{ }^{\circ} \mathrm{C}$. Therefore, it is unlikely that the Ar was able to escape via volume diffusion through the garnet. Hence, these ages likely reflect the timing of phengite inclusion into the growing garnet. Therefore, we interpret that at $44 \mathrm{Ma}$, garnet was still growing on the prograde path in the Lago di Cignana UHP unit, and that the Ar-Ar ages of Gouzu et al. (2006), as well as the U/Pb ages of Rubatto et al. (1998), date stages of the prograde metamorphic path. A Sm-Nd age of 40.6 $\pm 2.6 \mathrm{Ma}$ has been obtained for an eclogite from Lago di Cignana (Amato et al. 1999), and this was interpreted by these authors to date the peak metamorphism. This is supported by the fact that Sm is concentrated near the rim of the garnets in these samples (e.g. Skora et al. 2006). Note that the Sm-Nd age has been obtained from the same rock that Lapen et al. (2003) obtained their Lu-Hf isochron. Hence the age difference between $\mathrm{Lu}-\mathrm{Hf}$ and $\mathrm{Sm}-\mathrm{Nd}$ yields a minimum growth period for these garnets, which has been modelled to be 12 m.y. (Lapen et al. 2003).

Additional ages have been obtained from the Pfulwe area ( $\mathrm{T}_{\text {peak }} \sim 550-600{ }^{\circ} \mathrm{C}$; $\mathrm{P}_{\text {peak }} \sim 17-24$ (29) kbar, e.g. Oberhänsli 1980, 1982; Barnicoat \& Fry 1986; Ganguin 1988; Bucher et al. 2005). Lu-Hf isochron ages involving garnets scatter approximately around 52-48 Ma (Mahlen et al. 2005, 2006), similar to the Lu-Hf age obtained from the Lago di Cignana area. A Sm-Nd age of $54 \pm 18 \mathrm{Ma}$ from the Pfulwe area (Bowtell et al. 1994) is none constraining because of its large error. A signifi- cantly younger Lu-Hf age of around $40.8 \pm 1.8 \mathrm{Ma}$ (Mahlen et al. 2006), reported for the Saas Fee area $\left(\mathrm{T}_{\text {peak }} \sim 550-600{ }^{\circ} \mathrm{C}\right.$; $\mathrm{P}_{\text {peak }} \sim 20 \mathrm{kbar}$, Meyer 1983), has been interpreted by the authors to possibly indicate diachronous subduction of the Zermatt-Saas Fee ophiolite. A Sm-Nd garnet core age of $50.4 \pm 4.2 \mathrm{Ma}$ (Mayer et al. 1999) has been obtained in the St. Jacques/Val d'Ayas area $\left(\mathrm{T}_{\text {peak }} \sim 450{ }^{\circ} \mathrm{C}\right.$; $\mathrm{P}_{\text {peak }} \sim 10 \mathrm{kbar}$, Ernst \& Dal Piaz 1978), which should consequently date early stages of the prograde metamorphic path. $\mathrm{Rb}-\mathrm{Sr}$ ages of $\sim 42-45 \mathrm{Ma}$ were measured in phengites by Dal Piaz et al. (2001) from various localities in the Aosta region $\left(\mathrm{T}_{\text {peak }} \sim 500-600{ }^{\circ} \mathrm{C}\right.$; $\mathrm{P}_{\text {peak }} \sim 10-15$ kbar; e.g. Martin \& Tartarotti 1989; Dal Piaz et al. 2001), and these have been interpreted by these authors to date the peak of metamorphism.

\section{Petrology of the studied sample}

\section{Description}

This study focuses on garnet from an eclogite sample collected near the Pfulwe area ( $\sim 7 \mathrm{~km}$ E of Zermatt, Switzerland, coordinates (SUI): 630.646/096.146, $2940 \mathrm{~m}$, Fig. 1). It is the sample (and garnet data) described in Skora et al. (2006). The sample contains omphacite + garnet + paragonite + epidote/clinozoisite + glaucophane + rutile + apatite + opaque minerals. Mi-

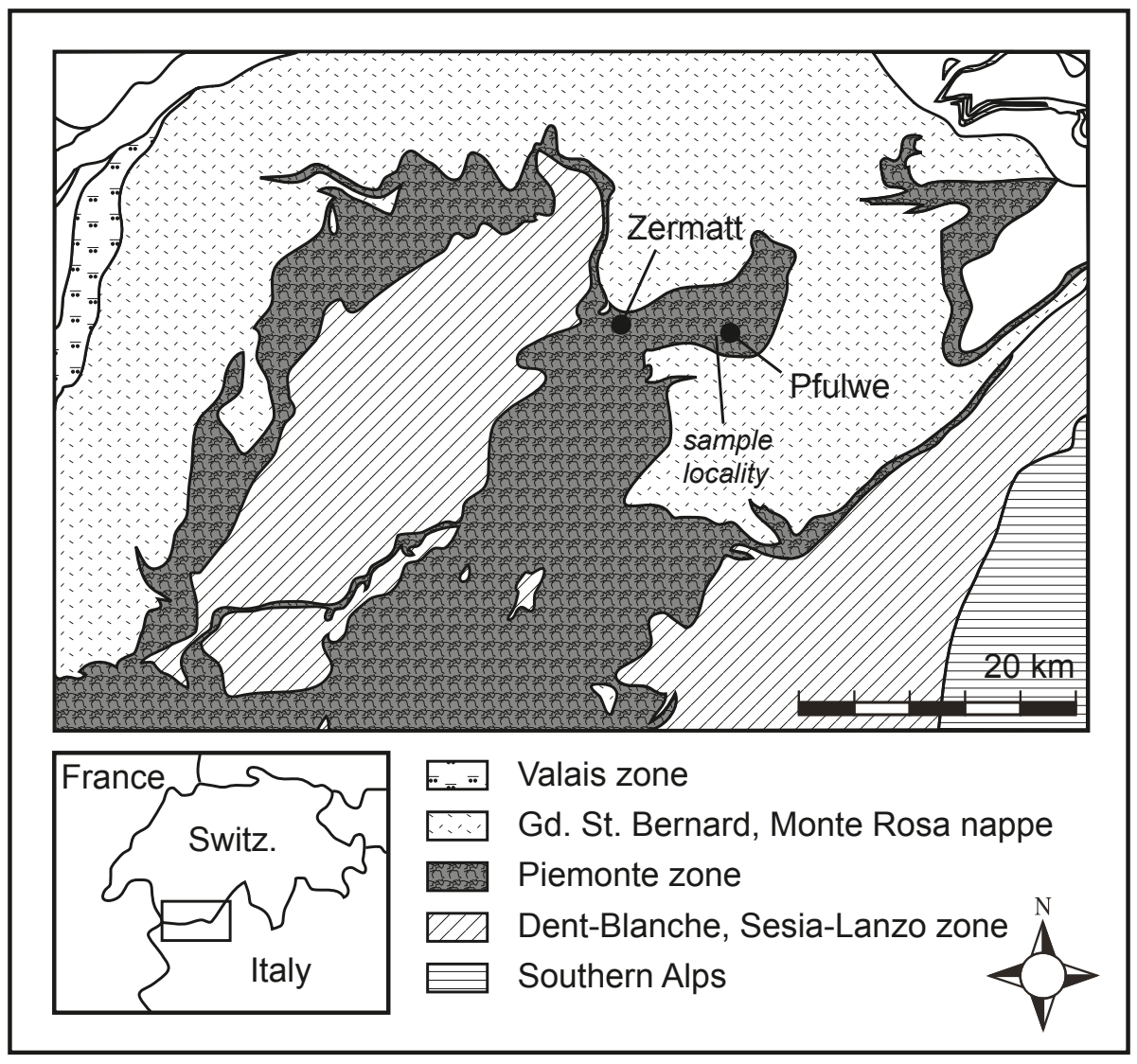

Fig. 1. Geologic map showing the exposures of the Liguro-Piemont oceanic remnants at the western Swiss/Italian border. 
croprobe measurements were carried out at the University of Lausanne using the method as described in Skora et al. (2006). Representative microprobe analyses are given in Table 1.

Omphacite is the most abundant matrix mineral with an estimated model abundance of $\sim 75 \%$. It is chemically homogeneous, with an average compositions of $50 \%$ jadeite, $34 \%$ diopside, $8 \%$ hedenbergite and $8 \%$ acmite (ferric iron was estimated based on stoichiometry of microprobe analyses, after Droop 1987). Omphacite mostly occurs as abundant small grains $(\sim 0.1-0.3 \mathrm{~mm})$ with undulatory extinction, and often preserve an original radial arrangement. The fact that radial bundles are locally preserved indicates low amounts of deformation. However, deformation led to a few parts within the sample where omphacites define a poorly developed foliation indicating that strain was localized along zones within the sample. Garnet grains are mostly euhedral and may be up to $1 \mathrm{~cm}$ in diameter. The spessartine and grossular content of garnet are highest in the cores whereas almandine and pyrope contents are highest towards the rims, indicative of prograde growth (e.g. Ghent 1988). The composition of the studied garnet varies from $\mathrm{Alm}_{56} \mathrm{Pyr}_{24} \mathrm{Gro}_{19} \mathrm{Spess}_{1}$ (rim) to $\mathrm{Alm}_{62} \mathrm{Pyr}_{14} \mathrm{Gro}_{19} \mathrm{Spess}_{5}$ (half way rim-centre) to $\mathrm{Alm}_{58} \mathrm{Pyr}_{10} \mathrm{Gro}_{20} \mathrm{Spess}_{12}$ (centre). All garnets typically contain abundant inclusions; rutile, glaucophane, and apatite were found throughout the garnets, epidote/clinozoisite inclusions occur mostly in the garnet cores, and omphacite typically occurs in high abundance toward the garnet rims. Garnet growth may have initiated during high blueschist/low eclogite-facies metamorphism, where glauco- phane and epidote/clinozoisite were present and omphacite growth had already started. Paragonites are nearly end-member in composition $\left(\mathrm{X}_{\mathrm{Na}} \sim 0.98\right)$ and occur evenly throughout the matrix. A second generation forms clusters or clots, up to a few $\mathrm{mm}$ in size, and are linked to vein-like, extensional structures. Most paragonites are aligned within the weak foliation where it is present (Fig. 2a). Some of the early paragonites are deformed or fractured, with the fractures partly filled with omphacites (Fig. 2b). Hence, while the large and clustered paragonites may be late, the dispersed ones are interpreted to have been present during the peak of the HP event, along with omphacite. All epidotes/clinozoisites $(\sim 0.1-1 \mathrm{~mm})$ are zoned with $\mathrm{Fe}-$ rich cores. The pistacite component varies from approximately $30-70 \%$ in this sample. Some of the epidotes clearly crosscut omphacites, indicating that at least some of them grew late. $\mathrm{Na}-\mathrm{Mg}$ amphiboles $\left(\mathrm{X}_{\mathrm{Mg}} \sim 70\right)$ occur in much lesser abundance than omphacite in the matrix and are nearly end-member glaucophane in composition $\left(\mathrm{X}_{\mathrm{Na}}(\mathrm{M} 4\right.$ site $) \sim 1.93$; amphibole formula calculated after Leake et al. (1997), Table 1). It is difficult to confirm if glaucophane was present during peak metamorphism, due to its very low abundance in this sample. The fact that they do occur as inclusions close to garnet rims indicate that they were stable at least close to peak metamorphic conditions.

Hence, the peak metamorphic assemblage of this sample was likely omphacite + garnet + paragonite + epidote/clinozoisite + rutile + apatite + glaucophane, followed by growth of retrograde epidote/clinozoisite + paragonite during early

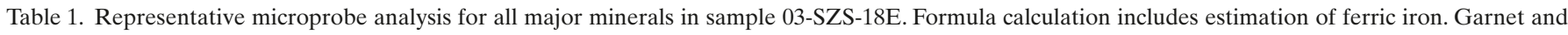

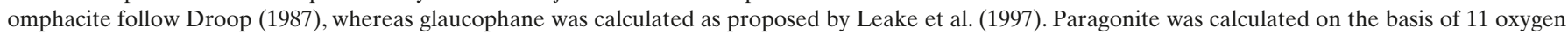
(assuming no ferric iron present). In contrast, epidote is calculated on the basis of 8 cations, assuming all iron is present as ferric iron.

\begin{tabular}{|c|c|c|c|c|c|c|c|c|c|c|}
\hline \multicolumn{11}{|c|}{ 03-SZS-18E } \\
\hline & grt-rim & middle & center & omp & omp & glc rim & core & pg & ep rim & core \\
\hline $\mathrm{SiO}_{2}$ & 38.51 & 37.89 & 37.60 & 56.43 & 56.24 & 57.58 & 58.22 & 46.83 & 38.75 & 38.05 \\
\hline $\mathrm{TiO}_{2}$ & 0.08 & 0.07 & 0.13 & 0.07 & 0.04 & 0.03 & 0.01 & 0.08 & 0.04 & 0.07 \\
\hline $\mathrm{Al}_{2} \mathrm{O}_{3}$ & 20.62 & 20.16 & 19.94 & 12.62 & 12.81 & 10.89 & 11.22 & 38.90 & 29.18 & 25.19 \\
\hline $\mathrm{FeO}$ & 26.04 & 28.95 & 25.99 & 5.43 & 4.55 & 11.20 & 9.95 & 0.52 & 5.10 & 9.89 \\
\hline $\mathrm{MnO}$ & 0.71 & 2.10 & 5.55 & 0.05 & 0.07 & 0.04 & 0.08 & 0.00 & 0.05 & 0.12 \\
\hline $\mathrm{MgO}$ & 6.30 & 3.80 & 2.45 & 6.39 & 6.80 & 9.84 & 10.48 & 0.16 & 0.01 & 0.00 \\
\hline $\mathrm{CaO}$ & 7.20 & 6.86 & 7.87 & 10.07 & 10.72 & 0.82 & 0.55 & 0.31 & 24.03 & 23.21 \\
\hline $\mathrm{Na}_{2} \mathrm{O}$ & 0.01 & 0.02 & 0.07 & 8.81 & 8.47 & 7.23 & 7.24 & 7.40 & 0.03 & 0.00 \\
\hline $\mathrm{K}_{2} \mathrm{O}$ & 0.00 & 0.01 & 0.01 & 0.00 & 0.00 & 0.03 & 0.02 & 0.67 & 0.01 & 0.00 \\
\hline Total & 99.48 & 99.85 & 99.64 & 99.87 & 99.70 & 97.68 & 97.80 & 94.89 & 97.24 & 96.59 \\
\hline $\mathrm{Si}$ & 3.01 & 3.01 & 3.01 & 1.99 & 1.99 & 7.92 & 7.93 & 3.01 & 3.00 & 3.01 \\
\hline $\mathrm{Al}^{\mathrm{IV}}$ & 0.00 & 0.00 & 0.00 & 0.01 & 0.01 & 0.08 & 0.07 & 1.00 & 0.00 & 0.00 \\
\hline $\mathrm{Al}^{\mathrm{VI}}$ & 1.90 & 1.89 & 1.88 & 0.52 & 0.52 & 1.69 & 1.73 & 1.95 & 2.66 & 2.35 \\
\hline $\mathrm{Ti}$ & 0.01 & 0.00 & 0.01 & 0.00 & 0.00 & 0.00 & 0.00 & 0.00 & 0.00 & 0.00 \\
\hline $\mathrm{Fe}^{3+}$ & 0.07 & 0.09 & 0.09 & 0.09 & 0.07 & 0.10 & 0.13 & 0.00 & 0.33 & 0.65 \\
\hline $\mathrm{Fe}^{2+}$ & 1.63 & 1.83 & 1.65 & 0.07 & 0.06 & 1.18 & 1.00 & 0.03 & 0.00 & 0.00 \\
\hline $\mathrm{Mn}$ & 0.05 & 0.14 & 0.38 & 0.00 & 0.00 & 0.00 & 0.01 & 0.00 & 0.00 & 0.01 \\
\hline $\mathrm{Mg}$ & 0.73 & 0.45 & 0.29 & 0.34 & 0.36 & 2.02 & 2.13 & 0.02 & 0.00 & 0.00 \\
\hline $\mathrm{Ca}$ & 0.60 & 0.58 & 0.68 & 0.38 & 0.41 & 0.12 & 0.08 & 0.02 & 1.99 & 1.97 \\
\hline $\mathrm{Na}$ & 0.00 & 0.00 & 0.00 & 0.60 & 0.58 & 1.93 & 1.91 & 0.92 & 0.00 & 0.00 \\
\hline $\mathrm{K}$ & 0.00 & 0.00 & 0.00 & 0.00 & 0.00 & 0.01 & 0.00 & 0.05 & 0.00 & 0.00 \\
\hline
\end{tabular}

640 S. Skora et al. 

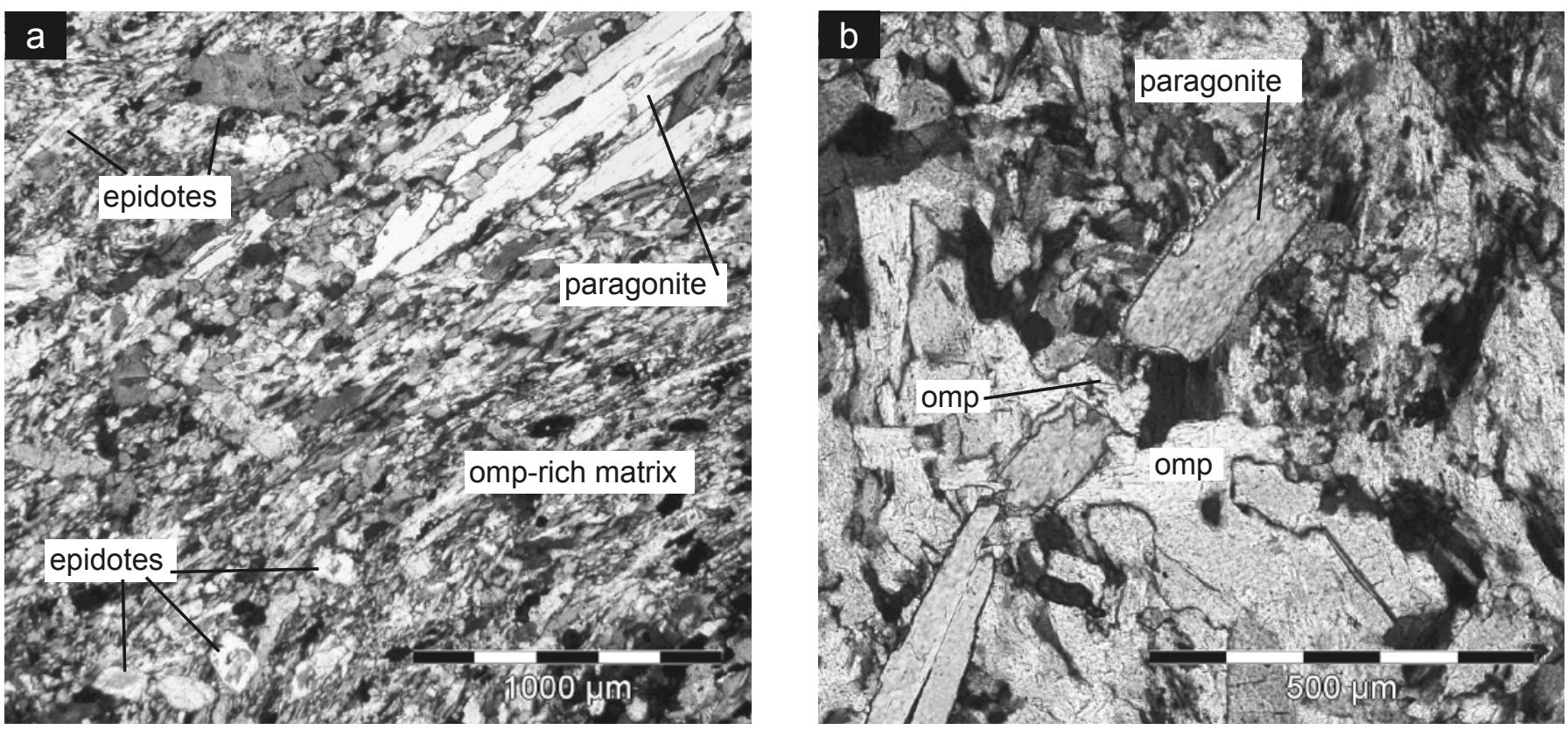

Fig. 2. a) Photomicrograph showing paragonites that are aligned within the fabric that is defined by omphacite.

b) Photomicrograph showing a broken paragonite crystal with omphacite filling the crack. Both observations suggest that paragonite was stable during peak metamorphism, along with omphacite.

stages of exhumation. Locally, upper greenschist-facies overprint produced mainly sodic-calcic hornblende (mainly taramites following the nomenclature of Leake et al. (1997)) \pm albite which occurs around garnet, paragonite, and glaucophane that are in contact with omphacite.

\section{Metamorphic conditions}

Using the software package Theriak-Domino of De Capitani (1994) and an updated thermodynamic database of Berman (1988), we calculated a pseudosection for the sample studied here (Fig. 3). The database contains thermodynamic data of Berman (1988, 1990), Evans (1990), McMullin et al. (1991) and Mäder et al. (1994). The thermodynamic estimate for daphnite from Vidal et al. (2001), and chloritoid data from Vidal et al. (1999) and (2001) were added, since they are consistent with the Berman (1988) database. Fe-glaucophane, epidote and Mn-chlorite thermodynamic data were taken from Holland \& Powell (1998) and corrected for consistency (De Capitani, personal communication). Solution models used are: Berman (1990) for garnet, Fuhrman \& Lindsley (1988) for feldspar and Meyre et al. (1997) for omphacite. Ideal mixing models (molecular mixing) were applied for the sodic-calcic amphiboles $(\mathrm{Fe}-\mathrm{Mg}$ pargasite $-\mathrm{Fe}-\mathrm{Mg}$ tschermakite $-\mathrm{Mg}-\mathrm{Fe}$ tremolite), $\mathrm{Mg}-\mathrm{Fe}$ glaucophanes, orthopyroxene (orthoenstatite - ferrosilite), olivine (fayalite - forsterite), chlorite (chlinochlor - daphnite - Mn chlorite), and Mg - Fe chloritoid.

Bulk rock chemistry was obtained with the XRF of the University of Lausanne. Trace amounts of potassium (found e.g. in trace amounts in paragonite (Table 1)) were ignored, as was Ti (basically only present in rutile), for simplification. Bulk rock XRF chemistry was further adjusted for phases that are not considered in the calculations. The Ca content was reduced by assuming that all measured phosphorus (XRF) belonged to apatite. Ferric iron is present in significant amounts in epidotes as well as in omphacites and glaucophanes. However, given that no reliable thermodynamic data exist for $\mathrm{Fe}^{3+}$ in omphacites and glaucophanes, we only considered the ferric iron present in epidotes. The latter has been estimated by combing modal abundances (estimated optically) with representative microprobe analyses (about $7 \%$ of the total iron). The chosen redox condition is included into the bulk rock chemistry by means of a simple calculation of how much oxygen is needed, assuming that $7 \%$ of the total iron is $\mathrm{Fe}^{3+}$.

The resulting pseudosection is shown in Figure 3. Given the presence of epidote, glaucophane and omphacites as inclusions in garnet (see above) as well as the absence of chloritoid and feldspar either as inclusions or in the matrix, it is likely that garnet growth was initiated below the chloritoid but above the feldspar stability, hence between $\sim 440-460{ }^{\circ} \mathrm{C}$ and $\sim 11-15 \mathrm{kbar}$. The calculated garnet-forming reaction is a chlorite consuming reaction given that the appearance of garnet is coeval with the disappearance of chlorite. The observed peak metamorphic assemblage of omphacite + garnet + paragonite + epidote/clinozoisite + possibly glaucophane is stable at about $580-620{ }^{\circ} \mathrm{C}$ and 17-23 kbar. An additional peak temperature estimate of $\sim 547 \pm 59^{\circ} \mathrm{C}$ (Fig. 4) was obtained using the $\mathrm{Mg} / \mathrm{Fe}$ exchange between 16 garnet-omphacite pairs (measured as close-by as 
03-SZS-18E= SI(54.17)AL(20.88)FE(5.59)MN(0.10)MG(7.87)CA(10.95)NA(14.55)O(172.16)H(100)O(50)

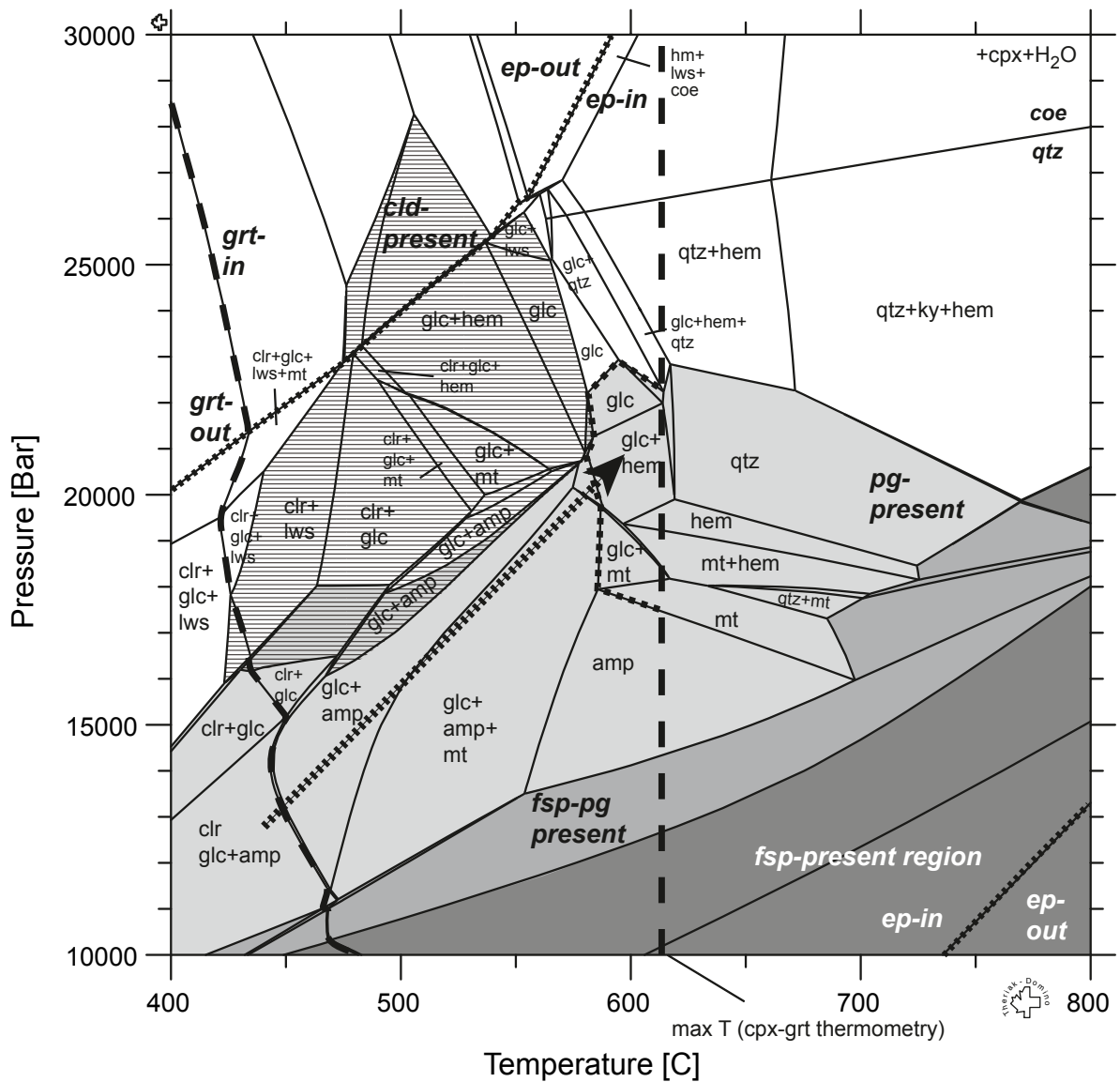

Fig. 3. Pseudosection for the investigated sample 03-SZS-18E, calculated with the Theriak-Domino software of De Capitani (1994) and an updated database from Berman (1988) (use of additional phases and solution models is discussed in the text). Note that the bulk chemistry is given in moles. Garnet growth was likely initiated below the chloritoid but above the feldspar stability, between $\sim 440-460{ }^{\circ} \mathrm{C}$ and $\sim 11-15 \mathrm{kbar}$ (see text). The peak metamorphic assemblage, omphacite + garnet + paragonite + epidote/clinozoisite + glaucophane, is stable between $580-620^{\circ} \mathrm{C}$ and $17-23$ kbar. $(\mathrm{chr}=$ chlorite; chd $=$ chloritoid; $\mathrm{fsp}=$ feldspar $;$ glc $=$ glaucophane; lws $=$ lawsonite grt = garnet; $\mathrm{pg}=$ paragonite $; \mathrm{amp}=$ sodic-calcic amphiboles; $\mathrm{mt}=$ magnetite; hem = hematite; ep = epidote $; \mathrm{qtz}=$ quartz; $\mathrm{cpx}=$ clinopyroxene $)$.

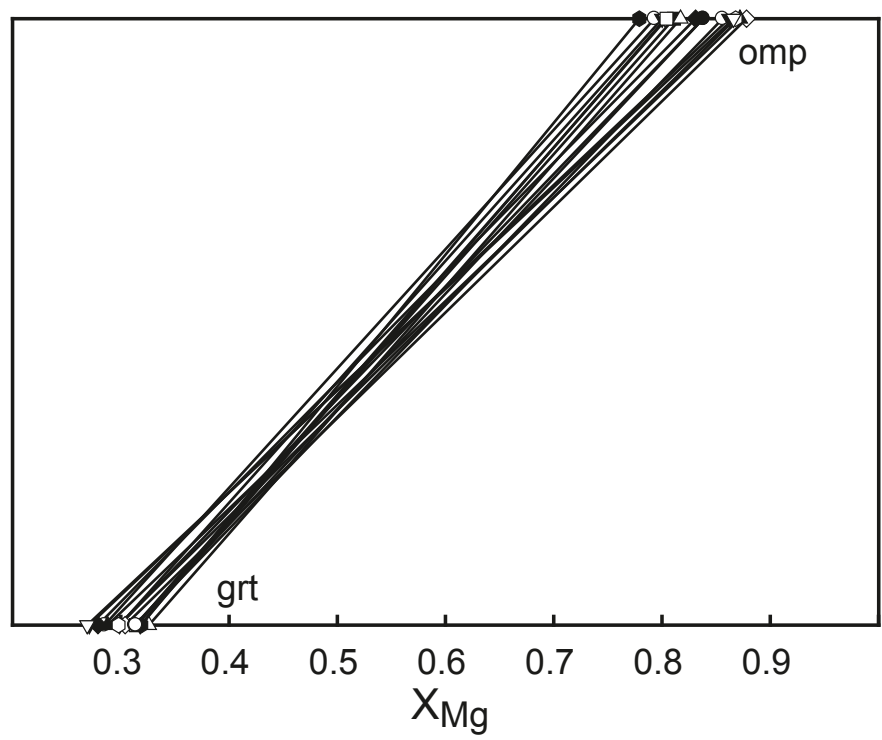

Fig. 4. $\mathrm{X}_{\mathrm{Mg}}$ equilibrium partitioning between omphacite and garnet, yielding a temperature estimate of $\sim 547 \pm 59^{\circ} \mathrm{C}$ using the updated calibration of Krogh (2000). Part of the variation in the $\mathrm{X}_{\mathrm{Mg}}$ is likely due to the ferric iron estimate. The latter is more problematic in omphacites as they contain significant amounts of ferric iron. possible), using the calibration of Krogh (2000). Temperatures were calculated assuming a pressure of $20 \mathrm{kbar}$. This garnetclinopyroxene temperature estimate is likely a minimum estimate because the real outermost borders of the garnets are replaced by small hornblende rims, and might have been slightly reset by retrograde diffusion of the bivalent cations. Using a peak metamorphic temperature of $580-620^{\circ} \mathrm{C}$ assumes that glaucophane belonged to the peak metamorphic assemblage. Note that the appearance of trace amounts of magnetite and hematite is due to errors in the estimation of the ferric iron content (the chosen $\mathrm{f}_{\mathrm{O} 2}$ ), and due to the lack of reliable thermodynamic data of other $\mathrm{Fe}^{3+}$-bearing phases.

Our estimate for peak metamorphic conditions in the Pfulwe area is largely consistent with previous studies. Earliest peak metamorphic conditions of eclogites in the Pfulwe area were around 14 kbar and $600{ }^{\circ} \mathrm{C}$ by Oberhänsli $(1980,1982)$ based on the jadeite-content in omphacite barometry and garnetomphacite thermometry. A later study pointed towards slightly higher conditions of $17.5-20 \mathrm{kbar}$ and $550-600{ }^{\circ} \mathrm{C}$ (Barnicoat \& Fry 1986), using the phase relation of the rare occurrence of kyanite \pm talc as upper limit. Ganguin (1988) estimated peak metamorphic temperatures of $550-575^{\circ} \mathrm{C}$ based on quartz-rutile oxygen isotope thermometry for the Täschalp-Pfulwe area. 


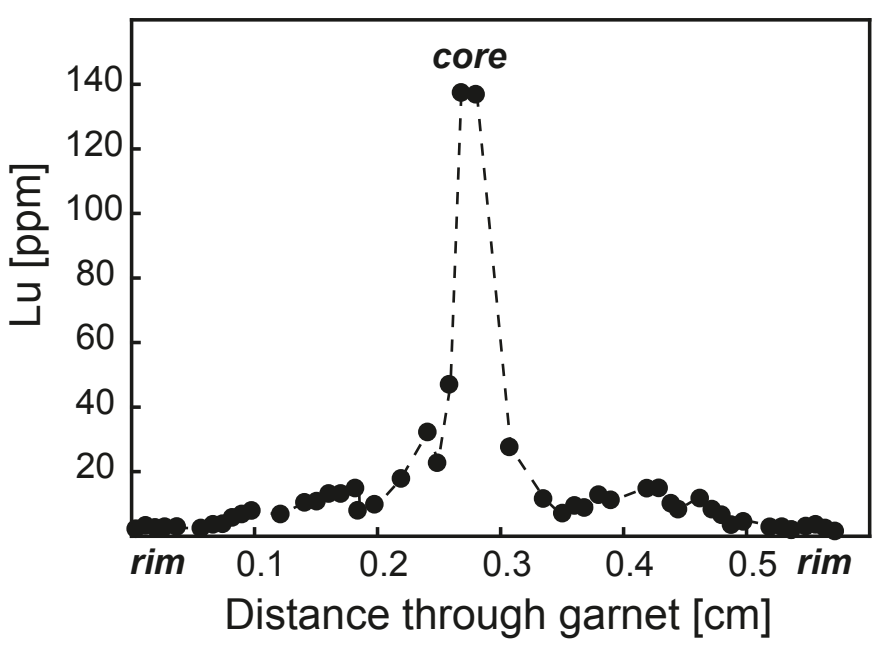

Fig. 5. Lu profile in the garnet, as published in Skora et al. (2006), Fig. 3. The Lu profile reveals a sharp central peak which decreases exponentially outwards. A second less pronounced maxima exists towards the rim. The analytical uncertainty is assumed to be $\pm 5-10 \%$.

Ganguin's pressure estimates of 18-24 kbar are based on several phase relations, e.g. the coexistence of chloritoid and talc. Chinner \& Dixon (1973) estimated peak metamorphic conditions for the nearby Allalin metagabbro mega boudin to be around $10-15 \mathrm{kbar}$ and $500-700{ }^{\circ} \mathrm{C}$. Meyer (1983) suggested a pressure higher than $20 \mathrm{kbar}$ and temperatures of $550-600{ }^{\circ} \mathrm{C}$ (max $660{ }^{\circ} \mathrm{C}$ ) for similar rocks, based on several phase relations as well as garnet-clinopyroxene thermometry. However, all studies including ours are in contrast to a recent study by Bucher et al. (2005) who suggested UHP conditions for the Pfulwe area based on the co-existence of talc and chloritoid and calculated phase relationships. This would suggest that all paragonites in the Pfulwe area grew retrograde, which stands in contrast to our microscopic observations for this sample, as well as for other samples from the Pfulwe area.

\section{Garnet REE geochemistry}

LA-ICP-MS/Ionprobe traverses reveal cores depleted in light rare earth elements (LREE $\mathrm{Sm}+\mathrm{Eu}+\mathrm{Gd}+\mathrm{Tb}$ ) along with at least one prominent peak towards the rim (e.g. Skora et al.2006). In contrast, the heavy rare earth elements (HREE $\mathrm{Lu}+\mathrm{Yb}+\mathrm{Tm}+\mathrm{Er}$ ) have narrow, exponentially decreasing central peaks as well as an additional, less pronounced but broad concentration maximum towards the rim (Fig. 5). The concentration decrease of the central peak is exponential and occurs over too short a distance to be explained by a pure Rayleigh distillation process. We have modelled the REE uptake as controlled by REE diffusion rates in the matrix surrounding the porphyroblast (Skora et al.2006). A low HREE matrix diffusion rate towards the growing garnet along with a high partition coefficient causes the central peak to decease very rapidly. In this case, diffusion of HREE towards the growing garnet is too slow to maintain a homogeneous concentration and steep diffusion halos develop in the surrounding matrix (Fig. 6).

\section{Maximum Lu volume diffusion rate estimate}

\section{Description of the model}

The survival of such sharp, prograde HREE peaks implies that, integrated, the garnet volume diffusion for REE was low during the P-T-t loop of the Zermatt-Saas Fee eclogites. We use the $\mathrm{Lu}$ peak in the garnet given in Figure 5 to infer maximum Lu volume diffusion rates. For this, the transient numerical diffusion model published in Skora et al. (2006) was extended to include volume diffusion in the garnet.

The model is a spherical system in which a single garnet nucleates and grows. Hence, the model solves the diffusion equation in spherical coordinates, which is given by

$\frac{\partial c}{\partial t}=D \frac{\partial^{2} c}{\partial r^{2}}+\frac{2 D}{r} \frac{\partial c}{\partial r}$

( $\mathrm{c}=$ concentration, $\mathrm{D}=$ diffusion rate at a given temperature, $\mathrm{r}=$ radius, $\mathrm{t}=$ time $)$. Lu uptake of the growing garnet is dependant on Lu diffusion rates towards the growing garnet, and the final rim composition of the precipitating garnet is calculated to be in equilibrium with the adjacent local matrix, using an equilibrium partition coefficient $\left(\mathrm{K}_{\mathrm{d}}\right)$. The matrix diffusion rate is calculated as a function of temperature along a fixed $\mathrm{P}-\mathrm{T}-\mathrm{t}$ path, following the Arrhenius equation

$D=D_{0} e^{-\frac{Q}{R T}}$

$\left(\mathrm{D}_{0}=\right.$ pre-exponential diffusion factor, $\mathrm{Q}=$ activation energy, $\mathrm{T}=$ temperature, $\mathrm{R}=$ universal gas constant). Volume diffusion within the garnet is calculated during prograde growth, and additionally during exhumation. The maximum volume diffusion rate that could have modified the initially sharp central peak is fitted to be the highest diffusion coefficient that still matches the innermost measured Lu concentrations.

The diffusion equation for the matrix as well as for garnet volume diffusion was solved numerically using a Crank-Nicholson scheme (Crank 1975). A no-flow symmetry boundary condition is applied for the centre of the sphere (left hand boundary at $r_{\text {garnet }}=0$ ) where the garnet nucleates. The rim composition of the growing garnet (right hand boundary condition at $r_{\text {garnet }}$ ) is always held at the value that precipitates due to diffusion-limited uptake of REE (Skora et al. 2006). The approach assumes that the fluxes of REE that may leave the system at the garnet surface during growth are insignificant, because of relatively low volume diffusion rates and generally low concentration gradients (outer parts of the garnet). In our case, large concentration gradients only occur in the innermost part which grew at low temperatures where volume diffusion was lowest. The applicability of such a constant composition 


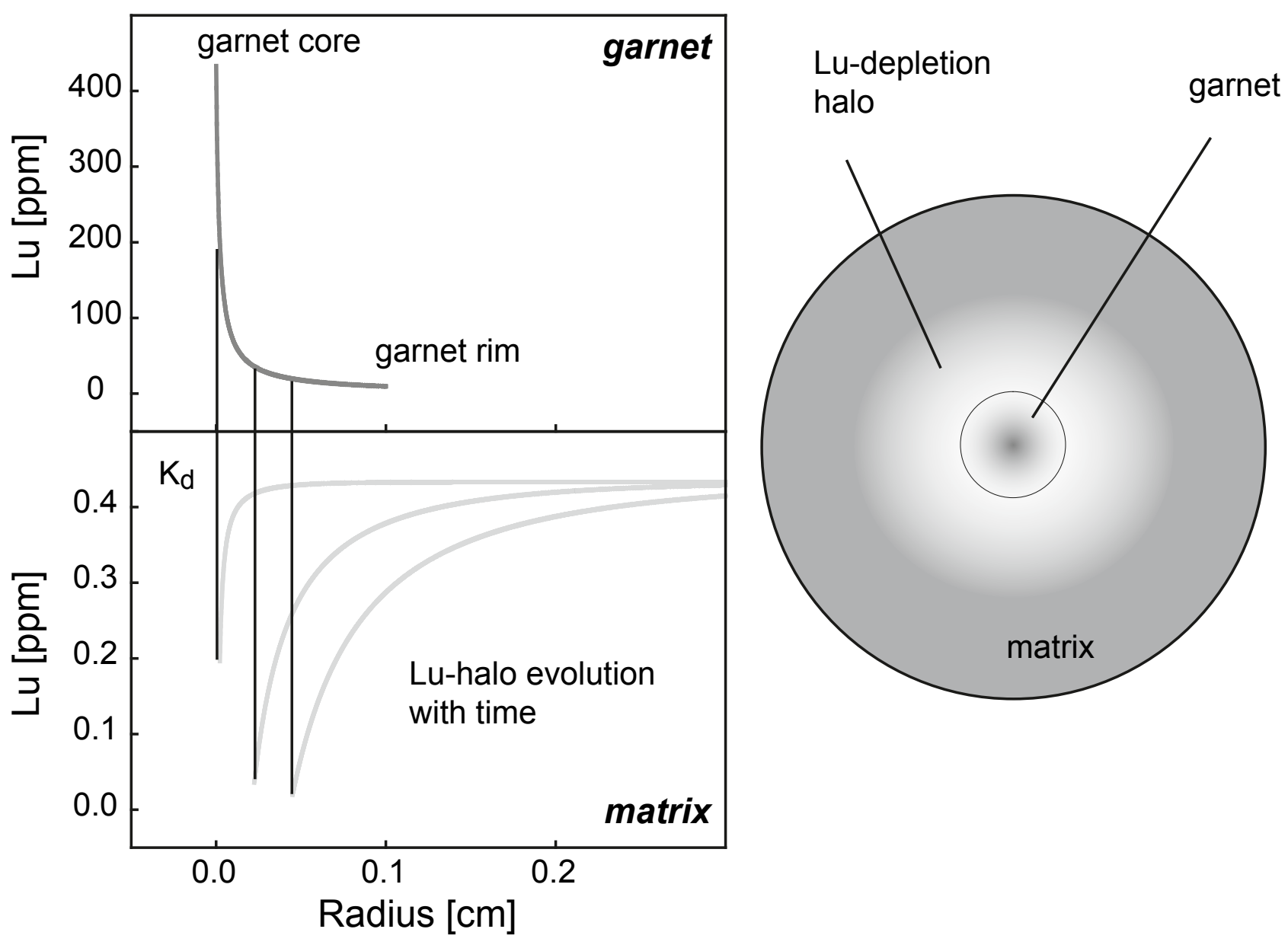

Fig. 6. Illustration of the development of the sharp, exponentially decreasing central Lu peak using a diffusion-limited REE uptake model. A low Lu matrix diffusion rate towards the growing garnet along with a high partition coefficient result in step diffusion halos in the surrounding matrix, which causes the central peak to decease very rapidly.

boundary condition at $r_{\text {garnet }}$ in our case is further justified by the fact that less than $<0.1 \%$ Lu contained in the garnet due to non-accounted flux across its outer rim is lost during the whole $\mathrm{P}-\mathrm{T}$ path, according to the overall mass balances calculated before and after a model run.

\section{Specific model conditions}

A prograde garnet growth interval of $450-600{ }^{\circ} \mathrm{C}$ for the eclogites outcropping at the Pfulwe pass is estimated based on the pseudosection (Fig. 3). Lapen et al. (2003) estimated a prograde growth interval of $12 \mathrm{~m}$.y. for ZSF eclogites in the Lago di Cignana UHP unit (coesite locality, Reinecke 1991, 1998). Similar Lu-Hf ages in both localities of around 48$52 \mathrm{Ma}$ (Mahlen et al. 2005, 2006) suggests that garnets in both areas might have had a similar prograde growth time interval. Temperature evolution was taken to increase non-linearly
$\left(\mathrm{T} \propto \mathrm{t}^{2}\right)$ to account for the fact that heating is more rapid once burial slowed during late subduction stages (e.g. Roselle \& Engi 2002). An average linear cooling rate of $\sim 50 \%$ m.y. was used for initial exhumation for a temperature interval of 600-250 ${ }^{\circ} \mathrm{C}$, as suggested by Amato et al. (1999). Subsequent slow exhumation rates, with an average linear cooling rate of $\sim 8^{\circ} / \mathrm{m}$.y. until $100{ }^{\circ} \mathrm{C}$, are estimated based on fission track data in adjacent units (Hurford et al. 1989, 1991; see discussion in Amato et al. 1999).

The activation energy ' $Q$ ', the pre-exponential diffusion factor ' $\mathrm{D}_{0}$ ' for REE matrix diffusion and the partition coefficient ' $K_{d}$ ' were fitted to the profiles. Slightly different parameters compared to Skora et al. (2006) with garnet-matrix Lu $\mathrm{K}_{\mathrm{d}}=5000, \mathrm{Q}=120 \mathrm{~kJ} / \mathrm{mol}$ and $\mathrm{D}_{0}=6.0 * 10^{-9} \mathrm{~m}^{2} / \mathrm{s}$ are needed to fully fit the innermost measurement and the initially very sharp, exponential decrease in the Lu concentration (Fig. 7a). We note that such a high garnet-matrix $\mathrm{Lu} \mathrm{K}_{\mathrm{d}}$ has never been

644 S. Skora et al. 
described in the literature (published garnet-omphacite $\mathrm{Lu}$ $\mathrm{K}_{\mathrm{d}}$ 's are rather in the order of 100-500, e.g. Sassi et al. 2000), but using a smaller $\mathrm{K}_{\mathrm{d}}$ does not fit the core-most Lu contents, and the resulting zoning profile would pass to the left of the innermost measurement. It is likely that such high $\mathrm{K}_{\mathrm{d}}$ 's would be difficult to detect in nature because imprecise central cuts, small amounts of volume diffusion as well as presently used analysis spot sizes would make such sharp peaks immeasurable. An extreme $K_{d}$ of 5000 was nevertheless chosen as input parameter in our model in order to maximize the amount of Lu below the peak. This assumption maximizes the diffusion distance and hence the diffusion coefficient estimate. It is important to note, however, that the $\mathrm{K}_{\mathrm{d}}$ does not exert a strong control on the diffusion modelling because the core-most $\mathrm{Lu}$ contents contribute a very small fraction of the Lu that is contained in the total garnet. The REE availability and transport in the matrix is likely a complex interplay of diffusion of REEs from within precursor minerals to their grain boundaries, as well as liberation of REEs from reacting minerals, followed by grain boundary diffusion towards the growing porphyroblast. The fitted diffusion parameters hence represent an apparent bulk diffusion coefficient for the individual REE in the matrix, including all above mentioned parameters and can thus not readily be compared to the experimental matrix diffusion data.

The activation energy ' $\mathrm{Q}$ ' for the $\mathrm{Lu}$ volume diffusion in garnet cannot be deduced from the measured Lu profile, since the restricted temperature time path does not define it accurately. Experimentally determined values for $\mathrm{REE}(\mathrm{Ce}, \mathrm{Nd}, \mathrm{Sm}$, $\mathrm{Dy}, \mathrm{Yb})$, as well as experimentally and naturally determined cation activation energies in alumosilicate garnet are consistently around $250-300 \mathrm{~kJ} / \mathrm{mol}$ (e.g. Chakraborty \& Ganguly 1991; Ganguly et al. 1998; Van Orman et al. 2002; Tirone et al. 2005; Carlson 2006). An activation energy of $270 \mathrm{~kJ} / \mathrm{mol}$ was used as input parameter.

\section{Result and sensitivity of the model}

The highest pre-exponential diffusion coefficient, along with the above discussed input parameters, which still fits the innermost measured Lu concentration is $\mathrm{D}_{0}=5.7 * 10^{-6} \mathrm{~m}^{2} / \mathrm{s}$ (Fig. 7a). This places a maximum estimate on the Lu diffusion coefficient for the given input parameters. Besides the central peak, volume diffusion did not significantly change the Lu concentration profile because the concentration gradients are significantly lower towards the rim.

In order to evaluate the sensitivity of the model we further calculated the resulting profile with a 5 times higher diffusion coefficient for comparison. Results show that the central peak would be strongly modified and the resulting profile passes well below our innermost measured value (Fig. 7b). Hence, the sharp central peak constrains well the maximum diffusion coefficients that could have operated during prograde growth and during exhumation for a given $\mathrm{P}-\mathrm{T}-\mathrm{t}$ trajectory.
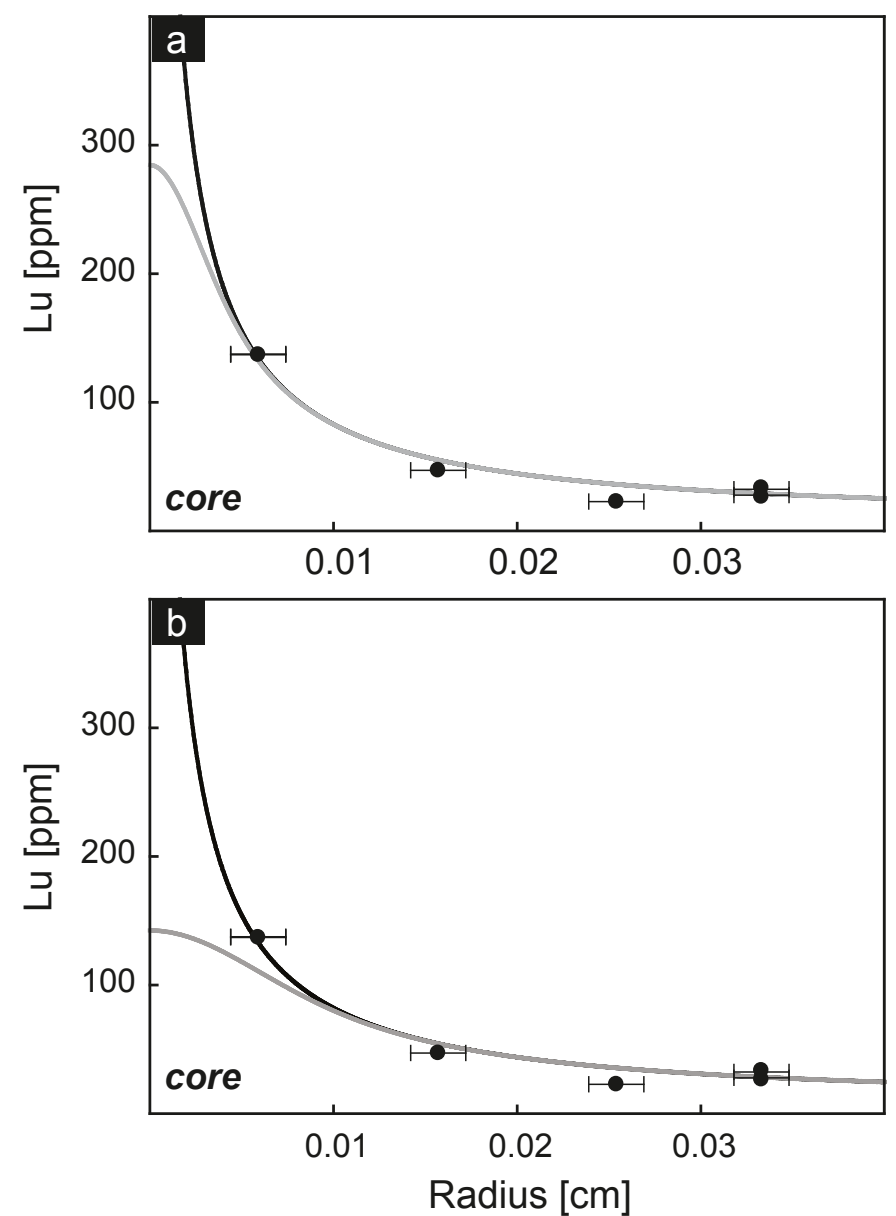

Fig. 7. a) Zoom of the central peak of the profile given in Fig. 5; Radius error bars correspond to the LA-ICP-MS pit size of $30 \mu \mathrm{m}$. Calculated fit is shown as a black solid line. It was calculated using the transient polythermal diffusion model in which Lu uptake is limited by diffusion through the matrix towards the growing garnet, neglecting volume diffusion. The modified profile is due to the maximum amount of Lu volume diffusion that could have been present in Alpine eclogite garnet during prograde growth and cooling, which still fits the core-most measured $\mathrm{Lu}$ concentration $\left(\mathrm{Q}=270 \mathrm{~kJ} / \mathrm{mol} ; \mathrm{D}_{0}=5.7^{*} 10^{-6} \mathrm{~m}^{2} / \mathrm{s}\right)$. b) Five times higher diffusion coefficient in the garnet would seriously modify the $\mathrm{Lu}$ peak and the resulting profile will not pass through the core-most measured $\mathrm{Lu}$ concentration $\left(\mathrm{Q}=270 \mathrm{~kJ} / \mathrm{mol} ; \mathrm{D}_{0}=2.9^{*} 10^{-5} \mathrm{~m}^{2} / \mathrm{s}\right)$. Hence, the sharp central Lu peak constrains well the maximum volume diffusion coefficient.

\section{Uncertainties}

The above fitted pre-exponential diffusion coefficient, $\mathrm{D}_{0}=5.7 * 10^{-6} \mathrm{~m}^{2} / \mathrm{s}$, is strongly dependent on the assumed input parameters, notably the choice of the T-t path and the activation energy. The latter is because of the long extrapolation between the integrated (along the chosen P-T-t path) diffusion temperature (which is close to the peak metamorphic temperature because of the strong temperature dependence of diffusion) and infinitely high temperatures at which $\mathrm{D}_{0}$ is defined. The choice of $\mathrm{Q}=270 \mathrm{~kJ}$ was made, after correcting the available activation energies for a 20 kbar pressure (result- 
Table 2. Summary of input parameters used and resulting diffusion coefficients.

\begin{tabular}{|c|c|c|c|c|c|c|c|}
\hline $\begin{array}{l}\mathrm{T}_{\text {start }} \\
{\left[{ }^{\circ} \mathrm{C}\right]} \\
\end{array}$ & $\begin{array}{l}\mathrm{T}_{\text {peak }} \\
{\left[{ }^{\circ} \mathrm{C}\right]}\end{array}$ & $\begin{array}{l}\Delta \mathrm{t} \\
{[\mathrm{m} . \mathrm{y} .]}\end{array}$ & T-t path & $\begin{array}{l}\mathrm{Q} \\
{[\mathrm{J} / \mathrm{mol}]}\end{array}$ & $\begin{array}{l}\mathrm{dT} / \mathrm{dt} \\
{[\% / \mathrm{m} . \mathrm{y} .]}\end{array}$ & $\begin{array}{l}\mathrm{D}_{\mathrm{o}} \\
{\left[\mathrm{m}^{2} / \mathrm{s}\right]}\end{array}$ & $\begin{array}{l}\left.D_{(\sim \text { peak }} \mathrm{T}\right) \\
{\left[\mathrm{m}^{2} / \mathrm{s}\right]}\end{array}$ \\
\hline 450 & 600 & 12 & $\mathrm{~T} \propto \mathrm{t}^{2}$ & 270000 & 50 & $5.7 * 10^{-6}$ & $4.0 * 10^{-22}$ \\
\hline 450 & 600 & 12 & $\mathrm{~T} \propto \mathrm{t}^{2}$ & 250000 & 50 & $3.3^{*} 10^{-7}$ & $3.7 * 10^{-22}$ \\
\hline 450 & 550 & 12 & $\mathrm{~T} \propto \mathrm{t}^{2}$ & 270000 & 50 & $4.4 * 10^{-5}$ & $3.3 * 10^{-22}$ \\
\hline 450 & 630 & 12 & $\mathrm{~T} \propto \mathrm{t}^{2}$ & 270000 & 50 & $1.7^{*} 10^{-6}$ & $4.2 * 10^{-22}$ \\
\hline 450 & 600 & 12 & $\mathrm{~T} \propto \mathrm{t}$ & 270000 & 50 & $3.0^{*} 10^{-6}$ & $2.1 * 10^{-22}$ \\
\hline
\end{tabular}

ing in $\sim 260-280 \mathrm{~kJ} / \mathrm{mol}$ ), taking an activation volume $\Delta \mathrm{V}$ for Mn of $6 \mathrm{~cm}^{3} / \mathrm{mol}$ (Chakraborty \& Ganguly 1991), as proposed by Tirone et al. (2005). However, an activation energy in the order of $250 \mathrm{~kJ} / \mathrm{mol}$ would significantly increase the fitted $\mathrm{D}_{0}$ to $3.3^{*} 10^{-7} \mathrm{~m}^{2} / \mathrm{s}$ whereas a higher activation energy of $300 \mathrm{~kJ} /$ mol would result into a $D_{0}$ in the order of $3.8^{*} 10^{-4} \mathrm{~m}^{2} / \mathrm{s}$. Hence, our maximum diffusion estimate might be better expressed as diffusion rate occurring at approximately peak metamorphic temperatures: $\mathrm{D}\left(\sim 600^{\circ} \mathrm{C}\right)=4.0^{*} 10^{-22} \mathrm{~m}^{2} / \mathrm{s}(\mathrm{Q}=270 \mathrm{~kJ} / \mathrm{mol})$, which is close to $\mathrm{D}\left(\sim 600{ }^{\circ} \mathrm{C}\right)=3.7^{*} 10^{-22} \mathrm{~m}^{2} / \mathrm{s} \quad(\mathrm{Q}=250 \mathrm{~kJ} /$ $\mathrm{mol})$ and $\mathrm{D}\left(\sim 600{ }^{\circ} \mathrm{C}\right)=4.3^{*} 10^{-22} \mathrm{~m}^{2} / \mathrm{s}(\mathrm{Q}=300 \mathrm{~kJ} / \mathrm{mol})$. A short discussion on other uncertainties will be given below by varying one parameter at a time, keeping the others constant (all diffusion and input parameters are summarized in Table 2).

Most peak metamorphic temperature estimates are on the order of $550-600{ }^{\circ} \mathrm{C}$. The choice of $\mathrm{T}=600{ }^{\circ} \mathrm{C}$ represents the mean temperature of our pseudosection modelling. A peak metamorphic temperature of only $550{ }^{\circ} \mathrm{C}$ would increase the $\mathrm{D}_{0}$ by slightly less than one order of magnitude $\left(D_{0}=4.4 * 10^{-5} \mathrm{~m}^{2} / \mathrm{s}\right.$; $\left.\mathrm{D}\left(\sim 550^{\circ} \mathrm{C}\right)=3.3^{*} 10^{-22} \mathrm{~m}^{2} / \mathrm{s}\right)$. This results because the same amount of diffusion would have to take place, but at significantly lower temperatures. As discussed above (metamorphic conditions), a peak metamorphic temperature of $550{ }^{\circ} \mathrm{C}$ is likely a minimum estimate. Similarly to an assumed lower peak temperature, an assumed higher peak temperature would lower the $\mathrm{D}_{0}$. Highest peak metamorphic temperature estimates for the ZSF zone are in the order of $630^{\circ} \mathrm{C}$ (e.g. Reinecke 1998), and would result in a $\mathrm{D}_{0}=1.7^{*} 10^{-6} \mathrm{~m}^{2} / \mathrm{s}$ and a $\mathrm{D}\left(\sim 630^{\circ} \mathrm{C}\right)=4.2^{*} 10^{-22} \mathrm{~m}^{2} / \mathrm{s}$.

A $\mathrm{T}-\mathrm{t}$ evolution with $\mathrm{T} \propto \mathrm{t}$ would result in an only slightly lower diffusion coefficient of $\mathrm{D}_{0}=3.0^{*} 10^{-6} \mathrm{~m}^{2} / \mathrm{s}\left(\mathrm{D}\left(\sim 600^{\circ} \mathrm{C}\right)\right.$ $=2.1 * 10^{-22} \mathrm{~m}^{2} / \mathrm{s}$ ). Our current studies indicate that the prograde growth period may have been much longer than the $\sim 12$ m.y. interval estimated by Lapen et al. (2003). Calculations with $\mathrm{t}=24 \mathrm{~m}$.y. also resulted in an insignificant change towards a lower diffusion coefficient of $\mathrm{D}_{0}=3.5^{*} 10^{-6} \mathrm{~m}^{2} / \mathrm{s}$ $\left(\mathrm{D}\left(\sim 600^{\circ} \mathrm{C}\right)=2.5^{*} 10^{-22} \mathrm{~m}^{2} / \mathrm{s}\right)$. This small change points towards the importance of how long the rock has spent close to peak metamorphic temperature rather than the whole garnet growth period, due to the strong temperature dependence of diffusion. Extending the growth period but leaving the $\mathrm{T}-\mathrm{t}$ evolution as is $\left(T \propto t^{2}\right)$ does not significantly change the time interval that the rock spent very close to peak metamorphic temperatures. For similar reasons, slower cooling rates of e.g. $30{ }^{\circ} \mathrm{C} / \mathrm{m}$.y. has no significant importance for the diffusion estimate $\left(\mathrm{D}_{0}=4.8^{*} 10^{-6} \mathrm{~m}^{2} / \mathrm{s}, \mathrm{D}\left(\sim 600^{\circ} \mathrm{C}\right)=3.4 * 10^{-22} \mathrm{~m}^{2} / \mathrm{s}\right)$.

\section{Comparison to experiments}

Only a few REE volume diffusion experiments in alumosilicate garnet exist at present (Sm: Harrison \& Wood (1980); Nd, Er: Coghlan (1990); Sm, Nd: Ganguly et al. (1998); Sm, Dy, Yb: Van Orman et al. (2002); Sm: Tirone et al. (2005)). Experimentally determined Lu diffusion data in alumosilicate garnet are not yet available. Extrapolation of Sm volume diffusion data estimated in pyrope crystals by Harrison \& Wood (1980) down to $600{ }^{\circ} \mathrm{C}$ results in diffusion rates which are approximately one order of magnitude higher. As already pointed out by Van Orman et al. (2002), a mechanism other than volume diffusion might be responsible for the low activation energies

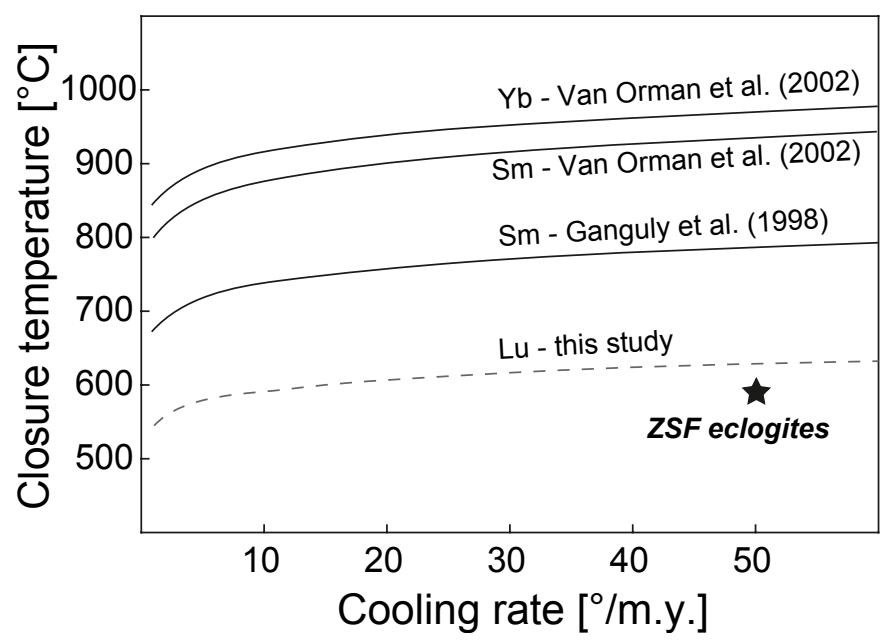

Fig. 8. a) Cooling rate versus closure temperature plot using the maximum $\mathrm{Lu}$ diffusion estimate of this study, as well as $\mathrm{Sm}$ and $\mathrm{Yb}$ diffusion data obtained from experiments on alumosilicate garnets (data corrected to $20 \mathrm{kbar}$ as discussed in the text; data of Van Orman et al. (2002) corrected for almandine-rich compositions; see Tirone et al. (2005)), using the Dodson equation. All calculations are performed for a garnet radius of $1 \mathrm{~mm}$. 


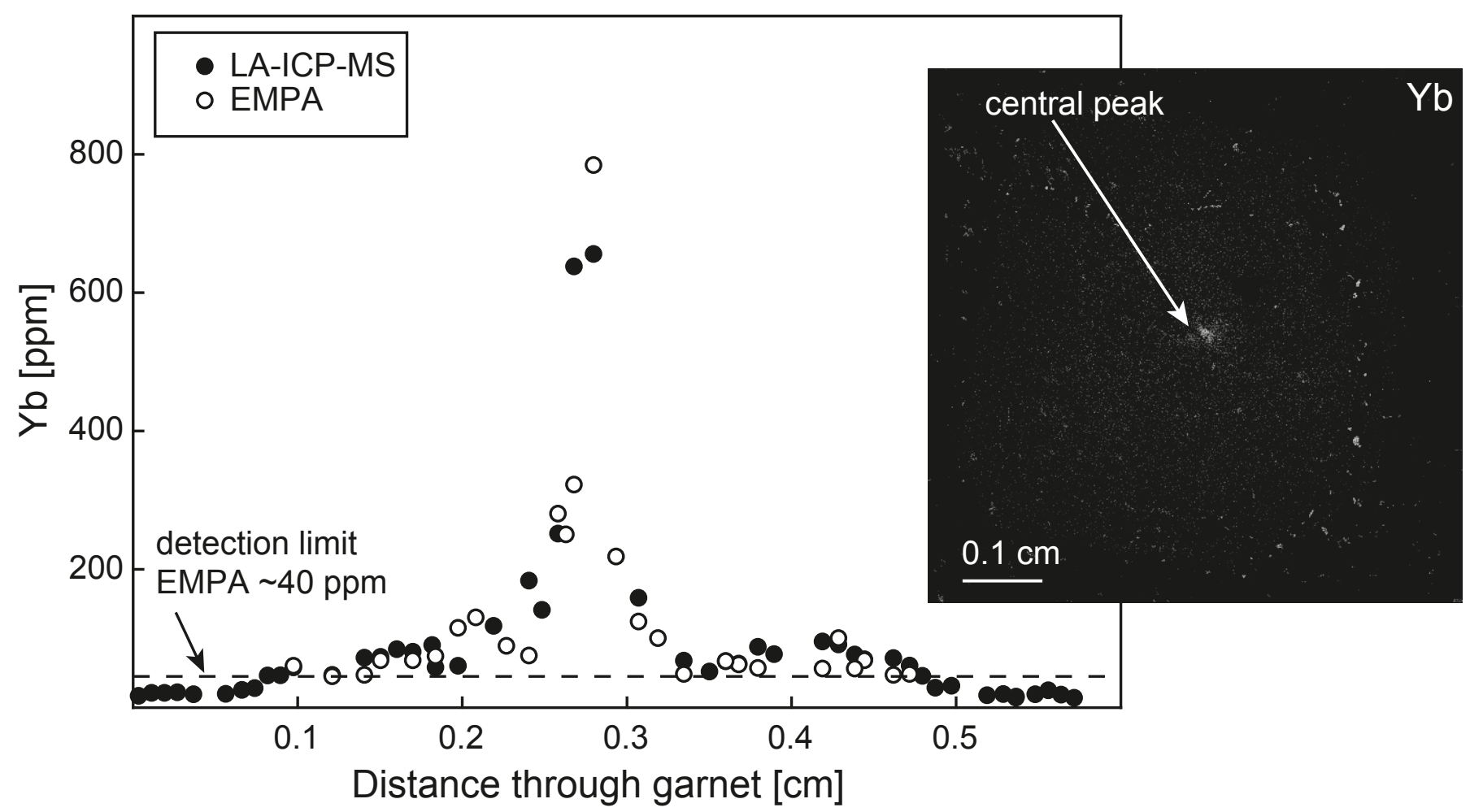

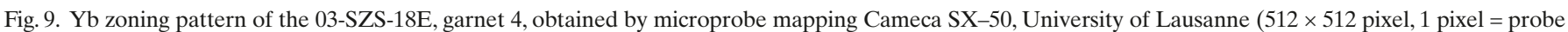

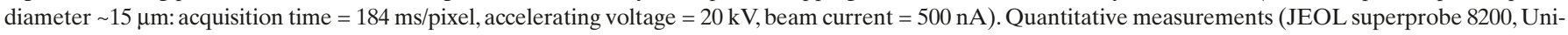

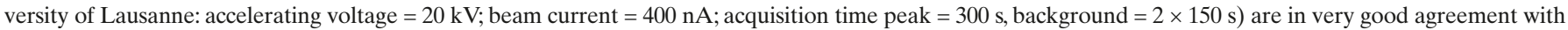
LA-ICP-MS data, highlighting the use of the microprobe for obtaining quick information on Yb zoning, which can be used as a proxy for Lu zoning pattern.

and high apparent diffusivities in this experiment. Volume diffusion data obtained in almandine-rich garnet for $\mathrm{Nd}$ and $\mathrm{Er}$ (Coghlan 1990), Sm and Nd (Ganguly et al. 1998; Tirone et al. 2005) are approximately 2-3 orders of magnitude slower than the Lu volume diffusion maximum estimate of this study, when extrapolated to $\mathrm{T}=600{ }^{\circ} \mathrm{C}$ and $\mathrm{P}=20 \mathrm{kbar}$ (using an activation volume $\left(6 \mathrm{~cm}^{3} / \mathrm{mol}\right)$ for Mn after Chakraborty \& Ganguly (1991), as proposed by Tirone et al. (2005)). Sm, Dy and Yb volume diffusion data obtained on a pyrope by Van Orman et al. (2002) are more than 5 orders of magnitude slower, even when corrected for almandine-rich compositions as proposed in Tirone et al. (2005).

\section{Implications for closure temperatures}

The $\mathrm{T}_{\mathrm{c}}$ for Lu-Hf garnet geochronology is generally assumed to be similar or higher than that for Sm-Nd geochronology (e.g. Duchêne et al. 1997; Scherer et al. 2000).

In principle, the closure temperature of Dodson (1973) represents the "point in time at which a completely mobile daughter product became virtually immobile", hence the $\mathrm{T}_{\mathrm{c}}$ will be dictated by the diffusion rates of $\mathrm{Hf}$ and $\mathrm{Nd}$. Two general trends can be found for REE + Hf diffusion in the literature. Some studies indicate a strong dependence on the ionic radius. Hence, slower diffusion for lighter REE (increasing ionic radii) (e.g. Van Orman et al. 2001 in clinopyroxene) is expected. Most other studies, including studies on garnet, have found only a weak or no dependence of REE diffusion on the REE ionic radius. Following the experimental results of Cherniak (1997a, 1997b) in zircon, it is likely that the tetravalent Hf, although smaller than the REE, diffuses more slowly than the trivalent REE. Taking together this information, we suggest that $\mathrm{D}(\mathrm{Hf})<\mathrm{D}(\mathrm{Nd}) \leq \mathrm{D}(\mathrm{Sm}) \leq \mathrm{D}(\mathrm{Lu})$. Given that a lower diffusion rate results in a higher $T_{c}$ (Dodson 1973), it follows that $\mathrm{T}_{\mathrm{c}}(\mathrm{Sm}-\mathrm{Nd})<\mathrm{T}_{\mathrm{c}}(\mathrm{Lu}-\mathrm{Hf}$ ) (see also Scherer et al. 2000). Hence, any diffusion coefficient of Lu can be used to constrain the minimum $\mathrm{T}_{\mathrm{c}}$ for both systems because $\mathrm{Lu}$ is inferred to diffuse at similar or higher rates than the other elements that are part of the Sm-Nd and Lu-Hf geochronological systems.

We performed minimum closure temperature calculations using equation (1) for garnet with a radius of $1 \mathrm{~mm}$, a typical size for ZSF eclogites, using the maximum diffusion estimate of this study. We further calculated the $\mathrm{T}_{\mathrm{c}}$ based on Sm diffusion of Ganguly et al. (1998) and for Sm and Yb (proxy for Lu) diffusion estimates of Van Orman et al. (2002) for comparison. Results are given in Fig. 8. $\mathrm{T}_{\mathrm{c}}$ estimates for initially very rapid cooling of around $50 \% \mathrm{~m}$.y. resulted in a minimum closure 
temperature estimate of around $630{ }^{\circ} \mathrm{C}$, using our maximum Lu diffusion coefficient estimate, while the use of the experimentally determined diffusion coefficients discussed above resulted in $\mathrm{T}_{\mathrm{c}}$ 's ranging from $\sim 780-970{ }^{\circ} \mathrm{C}$. We note that the maximum $\mathrm{T}_{\mathrm{c}}$ estimate based on the Lu diffusion rates of this study is close to the assumed peak metamorphic temperature of around $600{ }^{\circ} \mathrm{C}$ for the ZSF zone, although such a sharp Lu peak is preserved in the garnet. This is likely due to the strong temperature dependence of diffusion, which may preserve the prograde zoning up to temperatures close to the closure temperature. However, it can be concluded that $\mathrm{Sm}-\mathrm{Nd}$ and $\mathrm{Lu}-\mathrm{Hf}$ age differences in eclogite garnets from the Western Alps must be linked to prograde metamorphism and do not reflect different cooling temperatures because prograde zoning is preserved.

Due to the very large range of calculated closure temperatures using different experimental (Harrison \& Wood 1980; Coghlan 1990; Ganguly et al. 1998; Van Orman et al. 2002; Tirone et al. 2005) or field calibrations (e.g. Jagoutz 1988; Mezger 1992), it is not possible to decide whether a Sm-Nd or $\mathrm{Lu}-\mathrm{Hf}$ age data from high temperature eclogites or granulites represent the age of the end of garnet growth (peak of metamorphism assuming that $\mathrm{T}_{\text {peak }}$ and $\mathrm{P}_{\text {peak }}$ were reached more or less simultaneously) or cooling. Prograde growth zoning of cations and REE have to be preserved in garnets if it grew below its $T_{c}$. Hence, the presence of REE zoning patterns can be used as an indicator for low diffusion rates if the question arises whether a $\mathrm{Lu}-\mathrm{Hf}$ or $\mathrm{Sm}-\mathrm{Nd}$ age information age were reset. We further note that the presence of reset prograde REE zoning does not necessarily indicate that a Lu-Hf age is similarly reset, given that $\mathrm{Hf}$ is supposed to diffusion slower than REE (cited above).

REE zoning patterns are typically obtained by using laser ablation ICP-MS or ion probe techniques. An alternative approach is the use of electron microprobe measurements and element mapping. It is cheap to use and readily available. It can result in images and data quality that are good enough to constrain zoning for $\mathrm{Yb}$ provided that garnets are cut through their centres (Fig. 9). Sharp, central Yb peaks can be used as an indicator for low volume diffusion rates of $\mathrm{Lu}$, $\mathrm{Sm}, \mathrm{Nd}$ and $\mathrm{Hf}$ in garnet, assuming that $\mathrm{D}(\mathrm{Hf})<\mathrm{D}(\mathrm{Nd}) \leq$ $\mathrm{D}(\mathrm{Sm}) \leq \mathrm{D}(\mathrm{Yb}) \sim \mathrm{D}(\mathrm{Lu})$. This also implies that the closure temperature of a system has not been exceeded for a significantly long time.

\section{Acknowledgements}

Financial support of the Swiss National Science Foundation grant SNF2100066996 to L. Baumgartner and of the Société Académique Vaudoise to S. Skora is greatly acknowledged. We would like to thank K. Mezger, M. Cosca, and W. Carlson for pre-reviews, and C. De Capitani for his great help in the use of Theriak-Domino. The constructive reviews of J. Van Orman and M. Engi and the editorial handling of E. Gnos significantly improved the manuscript and were greatly appreciated.

\section{REFERENCES}

Amato, J., Johnson, C., Baumgartner, L., \& Beard, B. 1999: Rapid exhumation of the Zermatt-Saas ophiolite deduced from high-precision Sm-Nd and Rb-Sr geochronology. Earth and Planetary Science Letters 171, 425-438.

Barnicoat, A. \& Fry, N. 1986: High-pressure metamorphism of the ZermattSaas ophiolite zone, Switzerland. Journal of the Geological Society 143 , 607-618.

Barnicoat, A. 1988: The mechanism of veining and retrograde alteration of alpine eclogites. Journal of Metamorphic Geology 6, 545-558.

Bearth, P. 1967: Die Ophiolithe der Zone von Zermatt-Saas Fee. Beiträge zur geologischen Karte, Schweiz, 132, 130 pp.

Berman, R. 1988: Internally-consistent thermodynamic data for minerals in the system $\mathrm{Na}_{2} \mathrm{O}-\mathrm{K}_{2} \mathrm{O}-\mathrm{CaO}-\mathrm{MgO}-\mathrm{FeO}-\mathrm{Fe}_{2} \mathrm{O}_{3}-\mathrm{Al}_{2} \mathrm{O}_{3}-\mathrm{SiO}_{2}-\mathrm{TiO}_{2}-\mathrm{H}_{2} \mathrm{O}$ $\mathrm{CO}_{2}$. Journal of Petrology 29, 445-522.

Berman, R. 1990: Mixing properties of Ca-Mg-Fe-Mn garnets. American Mineralogist 75, 328-344

Bowtell, S., Cliff, R., \& Barnicoat, A. 1994: Sm-Nd isotopic evidence on the age of eclogitization in the Zermatt-Saas ophiolite. Journal of Metamorphic Geology 12, 187-196.

Brouwer, F.M., Burri, T., Engi, M., \& Berger, A. 2005: Eclogite relics in the Central Alps: PT - evolution, Lu-Hf ages and implications for formation of tectonic mélange zones. Schweizerische Mineralogische und Petrographische Mitteilungen 85, 147-174.

Bucher, K., Fazis, Y., De Capitani, C., \& Grapes, R. 2005: Blueschists, eclogites, and decompression assemblages of the Zermatt-Saas ophiolite: Highpressure metamorphism of subducted Tethys lithosphere. American Mineralogist 90, 821-835.

Carlson, W. 2006: Rates of Fe, Mg, Mn, and Ca diffusion in garnet. American Mineralogist 91, 1-11.

Cartwright, I., \& Barnicoat, A. 2002: Petrology, geochronology, and tectonics of shear zones in the Zermatt-Saas and Combin zones of the Western Alps. Journal of Metamorphic Geology 20,263-281.

Chakraborty, S. \& Ganguly, J. 1991: Compositional zoning and cation diffusion in garnets. In: Ganguly, J. (Ed.): Diffusion, atomic ordering and mass transfer. Springer Verlag, New York, 120-175.

Cherniak, D., Hanchar, J., \& Watson, E. 1997a: Diffusion of tetravalent cations in zircon. Contributions to Mineralogy and Petrology 127,383-390.

Cherniak, D., Hanchar, J., \& Watson, E. 1997b: Rare-earth diffusion in zircon. Chemical Geology 134, 289-301.

Chinner, G. \& Dixon, J. 1973: Some high-pressure parageneses of Allalin gabbro, Valais, Switzerland. Journal of Petrology 14, 185-202.

Coghlan, R. 1990: Studies of diffusional transport: grain boundary transport of oxygen in feldspars, strontium, and the REE's in garnet, and thermal histories of granitic intrusions in south-central Maine using oxygen isotopes. Unpublished $\mathrm{PhD}$ Thesis, Brown University, Providence.

Crank, J. 1975: The mathematics of diffusion. Oxford University Press, $414 \mathrm{pp}$.

Dal Piaz, G. \& Ernst, W. 1978: Areal geology and petrology of eclogites and associated metabasites of the Piemonte ophiolite nappe, Breuil-St.Jacques area, Italian Western Alps. Tectonophysics 51, 99-126.

Dal Piaz, G., Cortiana, G., Del Moro, A., Martin, S., Pennacchioni, G., \& Tartarotti, P. 2001: Tertiary age and paleostructural inferences of the eclogitic imprint in the Austroalpine outliers and Zermatt-Saas ophiolite, western Alps. International Journal of Earth Sciences 90, 668-684.

De Capitani, C. 1994: Gleichgewichts-Phasendiagramme: Theorie und Software. Beihefte zum European Journal of Mineralogy 72, 48.

Dewey, J., Helman, M., Turco, E., Hutton, D., \& Knott, S. 1989: Kinematics in the western Mediterranean. In: Coward et al. (Eds.): Alpine tectonics. Geological Society of London Special Publications 45, 265-283.

Dodson, M. 1973: Closure temperature in cooling geochronological and petrological systems. Contributions to Mineralogy and Petrology 40, 259-274.

Droop, G. 1987: A general equation for estimating $\mathrm{Fe}^{3+}$ concentrations in ferromagnesian silicates and oxides from microprobe analyses, using stochiometric criteria. Mineralogical Magazine 51, 431-435. 
Duchêne, S., Blichert Toft, J., Luais, B., Telouk, P., Lardeaux, J., \& Albarède, F. 1997: The Lu-Hf dating of garnets and the ages of the Alpine high-pressure metamorphism. Nature 387, 586-589.

Dunai, T.J. \& Roselieb, K. 1996: Sorption and diffusion of helium in garnet: implications for volatile tracing and dating. Earth and Planetary Science Letters 139, 411-421.

Ernst, W.G. \& Dal Piaz, G.V. 1978: Mineral paragenesis of eclogitic rocks and related mafic schists of the Piemonte ophiolite nappe, Breuil-St. Jacques area, Italian Western Alps. American Mineralogist 63, 621-640.

Escher, A., Hunziker, J., Marthaler, M., Masson, H., Sartori, M., \& Steck, A. 1997: Geodynamic evolution of the Tethyan margins of the Western Alps. In: Pfiffner et al. (Eds.): Deep structures of the Swiss Alps, Results of NRP 20. Birkhäuser Verlag, Basel, 205-221.

Evans, B. 1990: Phase-relations of epidote-blueschists. Lithos 25, 3-23.

Fuhrman, M. \& Lindsley, D. 1988: Ternary-feldspar modeling and thermometry. American Mineralogist 73, 201-215.

Ganguin, J. 1988: Contribution à la caractérisation du métamorphisme polyphase de la zone de Zermatt-Saas Fee (Alpes Valaisannes). Unpublished PhD thesis, ETH Zürich, 311 pp.

Ganguly, J., Tirone, M., \& Hervig, R. 1998: Diffusion kinetics of samarium and neodymium in garnet, and a method for determining cooling rates of rocks. Science 281, 805-807.

Ghent, E. 1988: A review of chemical zoning in eclogite garnets. In: Smith, D.C. (Ed.): Eclogite and eclogite-facies rocks. Elsevier, 207-236.

Gouzu, C., Itaya, T., Hyodo, H., \& Matsuda, T. 2006: Excess Ar-40-free phengite in ultrahigh-pressure metamorphic rocks from the Lago di Cignana area, Western Alps. Lithos 92, 418-430.

Harrison, W. \& Wood, B. 1980: An experimental investigation of the partitioning of REE between garnet and liquid with reference to the role of defect equilibria. Contributions to Mineralogy and Petrology 72, 145-155.

Holland, T. \& Powell, R. 1998: Internally consistent thermodynamic data set for phases of petrological interest. Journal of Metamorphic Geology 16, 309-343.

Hurford, A., Flisch, M., \& Jäger, E. 1989: Unravelling the thermotectonic evolution of the Alps: a contribution from fission track analysis and mica dating. In: Coward et al. (Eds.): Alpine tectonics. Geological Society of London Special Publications 45, 369-398.

Hurford, A., Hunziker, J., \& Stockhert, B. 1991: Constraints on the late thermotectonic evolution of the Western Alps - evidence for episodic rapid uplift. Tectonics 10, 758-769.

Jagoutz, E. 1988: Nd and Sr systematics in an eclogite xenolith from Tanzania - evidence for frozen mineral equilibria in the continental lithosphere. Geochimica et Cosmochimica Acta 52, 1285-1293.

Krogh, E. 2000: The garnet-clinopyroxene $\mathrm{Fe} 2+-\mathrm{Mg}$ geothermometer: an updated calibration. Journal of Metamorphic Geology 18, 211-219.

Lapen, T., Johnson, C., Baumgartner, L., Mahlen, N., Beard, B., \& Amato, J. 2003: Burial rates during prograde metamorphism of an ultra-high-pressure terrane: an example from Lago di Cignana, western Alps, Italy. Earth and Planetary Science Letters 215, 57-72.

Leake, B., Woolley, A., Arps, C., Birch, W., Gilbert, M., Grice, J., Hawthorne, F., Kato, A., Kisch, H., Krivovichev, V., Linthout, K., Laird, J., Mandarino, J., Maresch, W., Nickel, E., Rock, N., Schumacher, J., Smith, D., Stephenson, N., Ungaretti, L., Whittaker, E., \& Guo, Y. 1997: Nomenclature of amphiboles: Report of the subcommittee on amphiboles of the International Mineralogical Association, commission on new minerals and mineral names. American Mineralogist 82,1019-1037.

Mäder, U., Percival, J., \& Berman, R. 1994: Thermobarometry of garnet-clinopyroxene-hornblende granulites from the Kapuskasing structural zone. Canadian Journal of Earth Sciences 31,1134-1145.

Mahlen, N., Johnson, C., Baumgartner, L., Lapen, T., Skora, S., \& Beard, B. 2006: The protracted subduction history and HP/UHP metamorphism of the Zermatt-Saas ophiolite, western Alps, as constrained by Lu-Hf geochronology. EOS Trans. AGU Fall Meeting Supplement 87, V41E05 .

Mahlen, N., Skora, S., Johnson, C., Baumgartner, L., Lapen, T., Beard, B., \& Pilet, S. 2005: Lu-Hf geochronology of eclogites from Pfulwe, ZermattSaas ophiolite, western Alps, Switzerland. Supplement to Geochimica et Cosmochimica Acta 69, A305.
Martin, S. \& Tartarotti, P. 1989: Polyphase HP metamorphism in the ophiolitic glaucophanites of the lower St. Marcel Valley (Aosta, Italy). Ofioliti 14, $135-156$.

Masson, H., Bussy, F., Eichenberger, M., Giroud, N., Meilhac, C., \& Presniakov, S. in press: Early Carboniferous age of the Versoyen ophiolites and consequences: non-existence of a "Valais ocean" (Lower Penninic, Western Alps). Bulletin de la Societé Geologique de France.

Mayer, A., Abouchami, W., \& Dal Piaz, G. 1999: Eocene Sm-Nd age for the eclogitic metamorphism of the Zermatt-Saas ophiolite in Ayas Valley, Western Alps. European Union of Geosciences Meeting 10, A809.

McMullin, D., Berman, R., \& Greenwood, H. 1991: Calibration of the SGAM thermobarometer for pelitic rocks using data from phase-equilibrium experiments and natural assemblages. Canadian Mineralogist 29, 889908.

Meyer, J. 1983: Mineralogie und petrographie des Allalingabbros. Unpublished $\mathrm{PhD}$ thesis, Universität Basel, $329 \mathrm{pp}$.

Meyre, C., DeCapitani, C., \& Partzsch, J. 1997: A ternary solid solution model for omphacite and its application to geothermobarometry of eclogites from the Middle Adula nappe (Central Alps, Switzerland). Journal of Metamorphic Geology 15, 687-700.

Mezger, K., Essene, E., \& Halliday, A. 1992: Closure Temperatures of the Sm$\mathrm{Nd}$ System in metamorphic garnets. Earth and Planetary Science Letters $113,397-409$.

Müller, C. 1989: Albitization in the Zermatt Area, Western Alps. Unpublished $\mathrm{PhD}$ thesis, Universität Basel, $284 \mathrm{pp}$.

Oberhänsli, R. 1980: P-T-Bestimmungen anhand von Mineralanalysen in Eklogiten und Glaukophaniten der Ophiolite von Zermatt. Schweizerische Mineralogische und Petrographische Mitteilungen 60, 215-235.

Oberhänsli, R. 1982: The P-T history of some pillow lavas from Zermatt. Ofioliti 7, 431-436.

Purdy, J.W. \& Jäger, E. 1976: K-Ar ages on rock-forming minerals from the central Alps. Memorie degli Istituti di Geologia e Mineralogia dell' Università di Padova 30,1-32.

Reddy, S., Wheeler, J., \& Cliff, R. 1999: The geometry and timing of orogenic extension: an example from the western Italian Alps. Journal of Metamorphic Geology 17, 573-589.

Reinecke, T. 1991: Very-high-pressure metamorphism and uplift of coesitebearing metasediments from the Zermatt-Saas Zone, Western Alps. European Journal of Mineralogy 3, 7-17.

Reinecke, T. 1998: Prograde high- to ultrahigh-pressure metamorphism and exhumation of oceanic sediments at Lago di Cignana, Zermatt-Saas Zone, western Alps. Lithos 42, 147-189.

Roselle, G. \& Engi, M. 2002: Ultra high pressure (UHP) terrains: Lessons from thermal modeling. American Journal of Science 302, 410-441.

Rubatto, D., Gebauer, D., \& Fanning, M. 1998: Jurassic formation and Eocene subduction of the Zermatt-Saas-Fee ophiolites: implications for the geodynamic evolution of the Central and Western Alps. Contributions to Mineralogy and Petrology 132, 269-287.

Sartori, M. 1987: Structure de la zone du Combin entre les Diablons et Zermatt (Valais). Eclogae Geologicae Helvetiae 80, 789-814.

Sassi, R., Harte, B., Carswell, D.A., \& Yujing, H. 2000: Trace element distribution in Central Dabie eclogites. Contributions to Mineralogy and Petrology 139, 298-315.

Schaltegger, U., Desmurs, L., Manatschal, G., Muntener, O., Meier, M., Frank, M., \& Bernoulli, D. 2002: The transition from rifting to sea-floor spreading within a magma-poor rifted margin: field and isotopic constraints. Terra Nova 14, 156-162.

Scherer, E., Cameron, K., \& Blichert-Toft, J. 2000: Lu-Hf garnet geochronology: Closure temperature relative to the $\mathrm{Sm}-\mathrm{Nd}$ system and the effects of trace mineral inclusions. Geochimica et Cosmochimica Acta 64, 34133432 .

Skora, S., Baumgartner, L., Mahlen, N., Johnson, C., Pilet, S., \& Hellebrand, E. 2006: Diffusion-limited REE uptake by eclogite garnets and its consequences for Lu-Hf and Sm-Nd geochronology. Contributions to Mineralogy and Petrology 152, 703-720.

Stampfli, G., Mosar, J., Marquer, D., Marchant, R., Baudin, T., \& Borel, G. 1998: Subduction and obduction processes in the Swiss Alps. Tectonophysics 296, 159-204. 
Tirone, M., Ganguly, J., Dohmen, R., Langenhorst, F., Hervig, R., \& Becker, H. 2005: Rare earth diffusion kinetics in garnet: Experimental studies and applications. Geochimica et Cosmochimica Acta 69, 2385-2398.

Van Orman, J., Grove, T., \& Shimizu, N. 2001: Rare earth element diffusion in diopside: influence of temperature, pressure, and ionic radius, and an elastic model for diffusion in silicates. Contributions to Mineralogy and Petrology 141, 687-703.

Van Orman, J., Grove, T., Shimizu, N., \& Layne, G. 2002: Rare earth element diffusion in a natural pyrope single crystal at $2.8 \mathrm{GPa}$. Contributions to Mineralogy and Petrology 142, 416-424.

Vidal, O., Goffé, B., Bousquet, R., \& Parra, T. 1999: Calibration and testing of an empirical chloritoid-chlorite $\mathrm{Mg}$-Fe exchange thermometer and thermodynamic data for daphnite. Journal of Metamorphic Geology 17, 25-39.
Vidal, O., Parra, T., \& Trotet, F. 2001: A thermodynamic model for Fe-Mg aluminous chlorite using data from phase equilibrium experiments and natural pelitic assemblages in the 100 degrees to 600 degrees $\mathrm{C}, 1$ to $25 \mathrm{~kb}$ range. American Journal of Science 301, 557-592.

Villa, I.M. 1998: Isotopic closure. Terra Nova 10, 42-47.

Whitehouse, M. \& Platt, J. 2003: Dating high-grade metamorphism - constraints from rare-earth elements in zircon and garnet. Contributions to Mineralogy and Petrology 145, 61-74.

Manuscript received October 9, 2007

Manuscript accepted May 14, 2008

Published Online first: July 23, 2008

Editorial handling: Edwin Gnos 